\title{
Pericytes: multitasking cells in the regeneration of injured, diseased, and aged skeletal muscle
}

\author{
Alexander Birbrair ${ }^{1,2}$, Tan Zhang ${ }^{1}$, Zhong-Min Wang ${ }^{1}$, Maria L. Messi ${ }^{1}$, Akiva Mintz ${ }^{3}$ and \\ Osvaldo Delbono ${ }^{1,2 *}$
}

1 Department of Internal Medicine-Gerontology, Wake Forest School of Medicine, Winston-Salem, NC, USA

${ }^{2}$ Neuroscience Program, Wake Forest School of Medicine, Winston-Salem, NC, USA

${ }^{3}$ Department of Neurosurgery, Wake Forest School of Medicine, Winston-Salem, NC, USA

Edited by:

Ander Izeta, Instituto Investigación

Sanitaria Biodonostia, Spain

Reviewed by:

Aurel Popa-Wagner, University of

Medicine Rostock, Germany

Marni Della Boppart, University of

Illinois at Urbana-Champaign, USA

Cesare Gargioli, University of Rome

Tor Vergata, Italy

*Correspondence:

Osvaldo Delbono, Wake Forest

School of Medicine, Medical Center

Boulevard, Gray Building,

Winston-Salem, NC 27157, USA

e-mail: odelbono@wakehealth.edu
Pericytes are perivascular cells that envelop and make intimate connections with adjacent capillary endothelial cells. Recent studies show that they may have a profound impact in skeletal muscle regeneration, innervation, vessel formation, fibrosis, fat accumulation, and ectopic bone formation throughout life. In this review, we summarize and evaluate recent advances in our understanding of pericytes' influence on adult skeletal muscle pathophysiology. We also discuss how further elucidating their biology may offer new approaches to the treatment of conditions characterized by muscle wasting.

Keywords: pericytes, skeletal muscle, regeneration, innervation, fat formation, fibrous tissue, angiogenesis, aging

\section{INTRODUCTION}

In skeletal muscle, small blood vessels called capillaries surround each myofiber (Poole et al., 2008). The capillary wall consists of endothelial cells and pericytes. The latter are wrapped by the capillary basal lamina, located on the abluminal surface of the endothelial capillary tube. The word pericyte derives from the Greek kytos, a hollow vessel, appropriately describing a cell surrounding a blood vessel.

Electron microscopy studies estimated the pericyte-toendothelial-cell ratio for the overall coverage of microvessels in striated skeletal muscle as approximately 1:100 (Shepro and Morel, 1993). However, the analyzed samples were unstained, so the technique could not precisely distinguish pericytes from other surrounding cells. Pericytes are defined by their anatomical location in combination with several molecular markers (Kunz et al., 1994; Verbeek et al., 1994; Lindahl et al., 1997; Ozerdem et al., 2001), and the great advances in fluorescent imaging techniques suggest reanalyzing this ratio.

In most peripheral organs, pericytes are derived from the mesoderm (Armulik et al., 2011), but their origin in skeletal muscle has not been explored sufficiently. Specific pericyte subpopulations with distinct roles in the skeletal muscle have been described (Birbrair et al., 2013c). Whether pericyte subsets derive from different embryonic tissues remains unknown. CNS pericytes derive from the ectoderm (Bergwerff et al., 1998; Etchevers et al., 2001; Korn et al., 2002; Heglind et al., 2005). Brain pericytes exhibit both exclusive markers (Bondjers et al., 2006) and markers shared with skeletal muscle pericytes (Armulik et al., 2011). Whether and how pericyte functions in skeletal muscle differ from those in the brain remains to be explored. Brain and skeletal muscle pericytes express NG2 proteoglycan (Armulik et al., 2011; Birbrair et al., 2013c) and react to injury by forming fibrotic scars (Popa-Wagner et al., 2006; Dulauroy et al., 2012), suggesting that, independent of location, they share some properties.

Transplanting fluorescently marked embryonic tissues (e.g., mesoderm, endoderm, ectoderm, neural crest cells) into unmarked embryonic skeletal muscle may provide some clues on pericyte ancestors. Another approach would use transgenic mice for genetic tracking of cells from different embryonic tissues to pinpoint the origin of skeletal muscle pericytes and whether it differs for the recently identified subpopulations (Figure 1) (Birbrair et al., 2013a,c,d, 2014, 2015).

Pericytes are heterogeneous, exhibiting major differences depending on the tissue from which they have been isolated (Sims, 2000; Bondjers et al., 2006). Their functions seem to be tissue-specific, and very little is known about their function in skeletal muscle. Here, we present an overview of the current knowledge on their participation in adult muscle regeneration, reinnervation, vascularization, fibrosis, fat formation, and calcium deposition.

\section{PERICYTE PARTICIPATION IN SKELETAL MUSCLE REGENERATION}

Skeletal muscle comprises about $40 \%$ of the human body by weight. It is a highly organized network of different types of cells, neurovascular structures, and connective tissue. It may undergo physiological changes based on everyday physical activity, and due to its superficial location, it is constantly subjected to different grades of traumatic injury. Nevertheless, in young healthy 


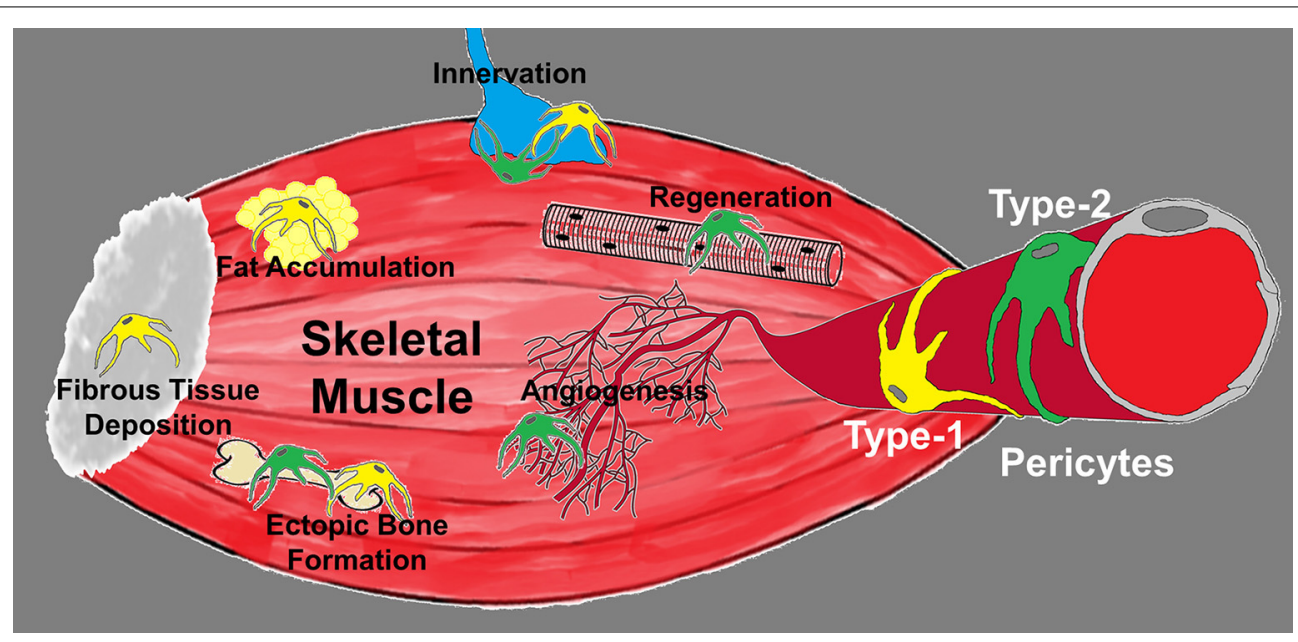

FIGURE 1 | Diagram depicting the roles of pericyte subtypes in skeletal muscle. Type-1 (yellow) and type-2 (green) pericytes are associated with blood vessels and differentially committed to tissue formation. Type-1 pericytes form adipose and fibrous tissue, while type-2 pericytes cooperate with myogenesis and angiogenesis. Their role in muscle innervation and ectopic bone deposition remains unexplored. subjects, skeletal muscle is well recognized for its remarkably robust endogenous capacity to repair itself (Huard et al., 2002; Cossu and Biressi, 2005; Relaix and Zammit, 2012). Functional loss of skeletal muscle mass and strength is observed with aging in a process known as sarcopenia (Delbono, 2011); as a secondary effect, known as cachexia, in some cancer patients; and due to trauma, vascular injuries, or degenerative muscle disorders, such as muscular dystrophy (Janssen et al., 2002; Acharyya et al., 2005; Glass, 2010; Vilquin et al., 2011). Muscle wasting can cause severe debilitating weakness and represents a significant clinical problem with few solutions (Vilquin et al., 2011). All of these conditions would benefit from approaches that promote skeletal muscle regeneration, but they would require complete understanding of the complexity of the cellular mechanisms involved.

The most well-studied myogenic cells in skeletal muscle are the muscle-specific stem cells called satellite cells, which are located between the basal lamina and sarcolemma of individual myofibers (Charge and Rudnicki, 2004; Zammit et al., 2006; Boldrin and Morgan, 2013). These cells participate in skeletal muscle repair in response to injury, but they are scarce and difficult to isolate (Berardi et al., 2014). Other problems include poor survival, incompatibility with systemic delivery, and host rejection (Giordano and Galderisi, 2010). Hence, researchers have explored and identified other skeletal muscle cells with high myogenic potential. They include muscle-derived stem cells (MDSCs; Lee et al., 2000; Qu-Petersen et al., 2002; Lavasani et al., 2006; Urish et al., 2009; Drowley et al., 2010); CD133+ progenitor cells (Torrente et al., 2004; Peault et al., 2007; Negroni et al., 2009); endothelial cells (Zheng et al., 2007); PW1+ interstitial cells (Mitchell et al., 2010; Pannerec et al., 2013); muscle side population (SP) cells (Gussoni et al., 1999; Asakura and Rudnicki, 2002; Bachrach et al., 2004); and pericytes (Dellavalle et al., 2007, 2011; Birbrair et al., 2013a,d).

Note that, besides cell therapy, all these cells may contribute to endogenous skeletal muscle formation, defined as the creation of new myofibers by proliferation, recruitment, migration and fusion of mononucleated cells (Yin et al., 2013).

The exact relationship between the different skeletal muscle cell types with myogenic potential and whether they all derive from one source have yet to be established. Future studies must define their specific contributions to muscle formation. One approach might be to use mouse models in which only one of these cell populations is ablated. Such a study showed that satellite cells are essential for skeletal muscle regeneration (Lepper et al., 2011; McCarthy et al., 2011; Murphy et al., 2011; Sambasivan et al., 2011). However, efficient skeletal muscle formation also depends on the interaction of cell types without myogenic potential, such as connective tissue fibroblasts (Barnes and Glass, 2011). In future studies ablating each of these cell populations separately, followed by skeletal muscle regeneration analysis, we may learn that they interact physically and release factors directly affecting each other's myogenic capacity.

Pericytes are myogenic in vitro (Dellavalle et al., 2007). When injected into injured skeletal muscle, they induce a higher muscle regenerative index than enriched myoblasts (Crisan et al., 2008b). Intra-arterial transplantation in animal models of muscular dystrophies demonstrated that they largely engrafted and may improve skeletal muscle function (Sampaolesi et al., 2003, 2006). Tedesco et al. (2012) found that transplantation of genetically modified pericytes resulted in functional amelioration of the dystrophic phenotype.

A more interesting question is whether endogenous pericytes contribute to skeletal muscle formation. Fate-tracking experiments with alkaline phosphatase (AP) Cre-ER mice proved that pericytes associated with blood vessels contribute to postnatal skeletal muscle growth by type; for example, less in tibialis anterior than diaphragm. They can assume satellite cells' position and become satellite cells (Dellavalle et al., 2011). Through unknown mechanisms, pericytes' contribution increases greatly during skeletal muscle regeneration in response to chemical injury (Dellavalle et al., 2011). Whether pericytes expand in the 
skeletal muscle following physical injury (for instance, in response to exercise) remains unknown; and, if so, whether the mechanisms are similar to those activated in response to chemical injury must be addressed (Boppart et al., 2013).

The molecular mechanisms activating and orchestrating pericytes' transition from quiescence to regenerating capacity in the skeletal muscle are also unknown. Again, whether selective ablation of pericytes from skeletal muscle will prevent or otherwise affect regeneration will clarify whether they can be replaced by other cell types with myogenic capacity. We propose that due to their ability to secrete several growth factors, pericytes may be required to induce other cell types to adopt a myogenic fate (Sato and Rifkin, 1989; Shepro and Morel, 1993; Davis et al., 1996; Yamagishi et al., 1999; Brown et al., 2001; Reinmuth et al., 2001; Hirschi et al., 2003; Niimi, 2003; Armulik et al., 2005; PaquetFifield et al., 2009; Shimizu et al., 2011). A global analysis of candidate growth factors secreted by skeletal muscle pericytes that promote skeletal muscle regeneration is required.

Our recent work reported the presence of two pericyte subpopulations in the skeletal muscle. Type-1 (Nestin-GFP-/NG2DsRed+) and type-2 (Nestin-GFP+/NG2-DsRed+) pericytes are in close proximity to blood vessel endothelial cells and co-localize with other pericytic markers (Birbrair et al., 2013c), but only type-2 is myogenic and participates in skeletal muscle regeneration (Birbrair et al., 2013a). Type-1 may not express the specific receptors needed to mediate the signaling pathways required for myogenic differentiation. Future studies should reveal the specific signaling pathways and why only one subpopulation can be induced to a myogenic fate. We also found that only type- 2 pericytes can enter the satellite cell compartment and express satellite cell marker Pax7 (Birbrair et al., 2013d).

The host microenvironment is critical for their myogenicity; for example, in older mice, the muscular regenerative capacity of type-2 pericytes is limited (Birbrair et al., 2013d), suggesting that it might be improved by modifying the deleterious aged muscle microenvironment. Approaches aimed at changing the old skeletal muscle environment have been reported. For instance, 3D hydrogel was used to rejuvenate pericytes derived from aged skeletal muscle, and their myogenic capacity improved (Fuoco et al., 2014).

To what extent impaired type-2 myogenicity leads to myofiber loss or skeletal muscle atrophy as compared to the effects of other myogenic cells in the skeletal muscle has yet to be defined. No one has yet studied whether intrinsic pericyte changes may impair skeletal muscle regeneration with aging, as recently reported in satellite cells (Bentzinger and Rudnicki, 2014; Bernet et al., 2014; Cosgrove et al., 2014; Sousa-Victor et al., 2014). Further, are pericyte autonomous changes with aging reversible? Is one pericyte subtype more prone to senescence or apoptosis? Does the aging environment select for a pericyte subtype with poorer myogenic potential? Does the number of distinct pericyte subpopulations change with aging and in diseased dystrophic skeletal muscle?

The only marker differentially expressed in skeletal muscle pericytes is Nestin-GFP, which is also expressed in satellite cells (Birbrair et al., 2011). Thus, only the combination of Nestin-GFP and NG2-DsRed expression distinguishes the pericyte subpopulations reported in the muscle interstitium (Birbrair et al., 2013c).
Future studies to determine whether the absence of endogenous type-2 pericytes compromises skeletal muscle regeneration, as with satellite cells (Barnes and Glass, 2011; Dellavalle et al., 2011; Lepper et al., 2011; McCarthy et al., 2011), will require discovery of novel markers selectively expressed in a pericyte subpopulation. To define them, investigators must first characterize the expression profiles of type- 1 and type- 2 pericytes. Better characterization may also advance therapies that target specific receptors. For instance, $\beta$-agonist therapy has shown potential in skeletal muscle repair (Beitzel et al., 2004); whether skeletal muscle pericytes express beta adrenergic receptors in response to these drugs is not known, although pericytes from other tissues do so (Kelley et al., 1988; Elfont et al., 1989; Ferrari-Dileo et al., 1992; Zschauer et al., 1996; Rucker et al., 2000; Quignard et al., 2003; Mendez-Ferrer et al., 2010a,b; Daly and McGrath, 2011; Lee et al., 2014).

Recent studies demonstrate that pericytes are involved in skeletal muscle regeneration as described above (Crisan et al., 2008b; Dellavalle et al., 2011; Birbrair et al., 2013a). However, the molecular mechanisms underlying the recruitment of pericytes in this complex process are unknown.

\section{PERICYTES IN SKELETAL MUSCLE REINNERVATION}

Muscle innervation is essential for maintaining mass and function with aging (Delbono, 2003, 2011). Denervation can result from trauma, immobility, unloading, infections, vasculitis, neuropathies, autoimmune processes, neoplasms, amyotrophic lateral sclerosis, and aging (Polak et al., 1988; Nikawa et al., 2004; Argiles et al., 2006; Glass, 2010; Bonaldo and Sandri, 2013). Loss of the nerve supply causes robust progressive skeletal muscle degeneration (Nikawa et al., 2004; Batt et al., 2006; Aagaard et al., 2010; Ohlendieck, 2011). Focal injuries to the peripheral nerves are often followed by complete recovery due to the capacity of peripheral axons to reoccupy neuromuscular junctions on denervated muscle fibers (Young, 1974; Rich and Lichtman, 1989; Nguyen et al., 2002). Even without nerve injury, the nerve terminal is constantly remodeled during degeneration and regeneration of skeletal muscle fibers, as this neuromuscular connection is needed for functional recovery of skeletal muscle (Li and Thompson, 2011). Rounds of denervation and reinnervation are evidenced by the random distribution of myofiber types across the skeletal muscle and their increased clustering with age (Larsson, 1995; Andersen, 2003; Rowan et al., 2012). Over the years, complete functional recovery is significantly reduced (Verdu et al., 2000; Kawabuchi et al., 2011). Whether these changes are controlled by the muscular, neural, or both systems is not known. Myofiber denervation has been demonstrated in mice and elderly humans (Hashizume et al., 1988; Kanda and Hashizume, 1989, 1992; Einsiedel and Luff, 1992; Doherty et al., 1993; Johnson et al., 1995; Zhang et al., 1996; Delbono, 2003; Aagaard et al., 2010; Valdez et al., 2010; Chai et al., 2011).

Regenerating axons grow through a complex microenvironment during the reinnervation process (Rich and Lichtman, 1989). They probably recognize and attach to postsynaptic sites guided by non-synaptic muscle fiber membranes and the membranes of glial cell processes (Kang et al., 2007). Schwann cells are widely believed to support axonal growth and to provide 
important cues that enable nerve fibers to reach the vacant synaptic sites (Chen et al., 2007). They also provide such important growth factors as neurotrophins, which ensure correct reinnervation after experimental nerve transection (Sendtner et al., 1992; Funakoshi et al., 1993; Friedman et al., 1996; Frostick et al., 1998; Brushart et al., 2013). Regenerating axons are guided by processes extended by terminal Schwann cells at the denervated synaptic location (Kang et al., 2014). Distinct Schwann cell populations have been described, including non-myelinating, myelinating, terminal, and perisynaptic Schwann cells, and terminal Schwannlike cells of sensory neuritis (Kwan, 2013). How their roles differ in skeletal muscle reinnervation remains poorly understood. The release of neurotrophic factors may be differentially regulated in these subpopulations. Schwann cells from young and old mice have been shown to differ both morphologically and in their ability to cover the motor endplate (Chai et al., 2011). The number of cells at the neuromuscular junction increases after skeletal muscle denervation, and based on Schwann cell markers, not all are Schwann cells (Magill et al., 2007). Future studies should determine the identity of the other cells and how they contribute to reinnervation. Whether pericytes participate remains largely unexplored.

Previous studies have demonstrated that CNS perivascular pericytes can form cells that express glial markers (Dore-Duffy et al., 2006; Bonkowski et al., 2011; Jung et al., 2011; Nakagomi et al., 2011). In skeletal muscle, cells in the interstitial space differentiate into glial lineage (Romero-Ramos et al., 2002; Alessandri et al., 2004; Kondo et al., 2006; Schultz and Lucas, 2006; Arsic et al., 2008; Birbrair et al., 2011). We recently demonstrated that under optimized skeletal muscle culture conditions, only type2 pericytes form oligodendrocyte progenitors (Birbrair et al., 2013b,c), which produce mature oligodendrocytes and Schwann cells (Zawadzka et al., 2010). Whether type-2 pericytes contribute to Schwann cell populations generally and to the newly formed Schwann cells that participate in skeletal muscle reinnervation specifically remains to be addressed.

Also, to what degree do these endogenous pericytes influence the reoccupation of synaptic sites during reinnervation? Recently, cells isolated from adult human skeletal muscle were shown to differentiate into myelinating Schwann cells and to ameliorate a critical-sized sciatic nerve injury in a murine model. Denervated skeletal muscles from treated mice exhibit substantially decreased atrophy, and the motor endplates at the postsynaptic sites reorganize (Lavasani et al., 2014). Although this study provides evidence for the therapeutic capability of skeletal muscle-derived cells in vivo, it did not identify these cells. As the skeletal muscle cell environment is heterogenous, future work should focus on identifying muscle-derived cells that can repair the sciatic nerve after injury. We reported that only type- 2 pericytes have gliogenic potential in the skeletal muscle (Birbrair et al., 2013c), so they are immediate candidates for testing. Tracking pericyte fate by an inducible Cre system after skeletal muscle denervation will be required to address pericyte potential to form Schwann cells.

As there are several types of Schwann cells (Kwan, 2013), it would be interesting to explore whether pericytes form a specific subtype. The Wnt/beta-catenin signaling pathway is active in $\mathrm{NG} 2+$ cells differentiating into NG2 glia cells in the brain (White et al., 2010). As pericytes express NG2 proteoglycan and form NG2 glia cells (Birbrair et al., 2013b,c), this pathway might be activated to induce skeletal muscle reinnervation.

To understand the role of pericytes in neuromuscular junction regeneration, future studies should test the effect of ablating them after sciatic nerve injury. Mouse models using viral thymidine kinase to genetically deplete pericytes are viable and have been used recently (Cooke et al., 2012; Lebleu et al., 2013). As Schwann cells have the capacity to dedifferentiate into immature cells after sciatic nerve injury (Yang et al., 2012), do they ever become pericytes?

We envision that determining exactly what happens after denervation may provide cellular targets for pharmacological manipulation to improve skeletal muscle reinnervation. At present, the role of pericytes in this process is only speculative.

\section{PERICYTE CONTRIBUTION TO VESSEL FORMATION IN SKELETAL MUSCLE}

Blood supply to the skeletal muscle can be compromised after vascular injury, bone fracture, and crush injury (Blaisdell, 2002) and by complications due to such cardiovascular and metabolic diseases as atherosclerosis, heart failure, diabetes, and obesity (Baumgartner et al., 2005; Varu et al., 2010; Chi et al., 2011). In addition, the number of capillaries and arteries feeding the skeletal muscle decreases with age (Conley et al., 2000; Behnke et al., 2006), compromising its perfusion (Wahren et al., 1974; Irion et al., 1987). Compared to young mice, the capacity of old mice to form new blood vessels (angiogenesis) is impaired (Rivard et al., 1999; Shimada et al., 2004; Yu et al., 2006).

When the blood supply to tissue is partially obstructed, oxygen content decreases, leading to ischemia (Forsythe et al., 1996; Heil and Schaper, 2004). Collateral arteries and anastomoses can partially restore blood flow (Heil and Schaper, 2004), attenuating the damage caused by hypoxia, but even short-term ischemia induces necrosis, leading to inflammatory reactions. After only $5 \mathrm{~h}$, an ischemic environment causes necrosis in 90 percent of skeletal muscle (Labbe et al., 1987). If revascularization fails, it can lead to limb amputation (Conrad et al., 2011). While exercise is a potent stimulus for new vessel formation in adult skeletal muscle (Booth and Thomason, 1991; Egginton, 2009), most of the conditions leading to skeletal muscle ischemia preclude exercise.

Angiogenesis is a complex process in which new blood vessels form from existing ones. It involves extensive interplay between cells and growth factors, extracellular matrix proteins, proteases, and adhesion molecules (Folkman, 1971; Caduff et al., 1986; Kilarski et al., 2009). The exact cellular mechanisms of physiological angiogenesis in skeletal muscle remain poorly understood. It requires the proliferation and migration of endothelial cells to line the interior of the blood vessels (Rousseau et al., 2000; Li et al., 2005; Lamalice et al., 2006). Macrophages and other inflammatory cells (Barbera-Guillem et al., 2002; Shireman, 2007) infiltrate the tissues after ischemia (Sica, 2010; Alexander et al., 2011) and, together with fibroblasts and myofibers (Gustafsson et al., 1999; Steinbrech et al., 1999), secrete such angiogenic molecules as vascular endothelial growth factor (VEGF), placenta growth factor (PlGF), fibroblast growth factor 2 (FGF2), and platelet-derived 
growth factor (PDGF; Lewis and Murdoch, 2005; Murdoch and Lewis, 2005; Murdoch et al., 2005), which are necessary to construct new blood vessels and to restore blood perfusion.

Pericytes also participate in the formation of new blood vessels (Egginton et al., 1996; Hellstrom et al., 1999; Gerhardt and Betsholtz, 2003; Bergers and Song, 2005). This participation includes phenotype changes, migration, alignment, and contacts with endothelial cells. Pericytes are the first cells to invade newly vascularized tissues (Diaz-Flores et al., 1991; Nehls et al., 1992; Reynolds et al., 2000). The hypoxic state stimulates pericyte migration and angiogenesis (Murata et al., 1994). They adopt angiogenic phenotype by shortening their processes and increasing their somatic volume (Diaz-Flores et al., 1992b, 1994b). Autoradiographic studies show that the proliferation of these activated pericytes increases (Schoefl, 1963; Cavallo et al., 1972, 1973; Sholley et al., 1977; Burger and Klintworth, 1981; Diaz-Flores et al., 1992b, 1994a,b). Pericytes guide and determine where the newly formed blood vessels spread (Nehls et al., 1992; Tsuzuki and Sasa, 1994; Ozerdem et al., 2001; Morikawa et al., 2002; Ozerdem and Stallcup, 2003) and promote endothelial cell survival (Amselgruber et al., 1999; Morikawa et al., 2002; Darland et al., 2003; Kale et al., 2005). They can form tubes (Moldovan et al., 2000; Anghelina et al., 2002, 2004, 2006; Ozerdem and Stallcup, 2003) and penetrate endothelial cells. They prevent vessel regression (Benjamin et al., 1998, 1999; Enge et al., 2002). Pericytes express PDGF receptors and respond to PDGF (Balabanov et al., 1996). Their recruitment is crucial for vessel maturation, as the lack of PDGF disrupts vessel development (Lindahl et al., 1997; Hellstrom et al., 2001). Following exercise, NF- $\kappa \mathrm{B}$, a strong inducer of angiogenesis, is activated in a pericyte sub-population (Hyldahl et al., 2011). Under hypoxic conditions, VEGF from pericytes can stimulate other pericytes to proliferate and migrate (Yamagishi et al., 1999).

The process of angiogenesis depends on appropriate cell signaling based in the tissue microenvironment, so most of our data comes from in vivo studies. Dissecting and occluding the femoral artery to induce brief ischemia is a common model for studying physiological angiogenesis (Shireman and Quinones, 2005; Westvik et al., 2009).

Therapeutic angiogenesis has been pursued as a potential treatment for ischemic disorders (Isner and Asahara, 1999; Ferrara and Kerbel, 2005; Giacca and Zacchigna, 2012). Its goal is to stimulate blood vessels to grow new blood vessels (Folkman, 1995; Isner, 1996; Ferrara and Kerbel, 2005). Several cell types have been used to induce neovascularization (Kalka et al., 2000; Hamano et al., 2001; Shintani et al., 2001; Iwase et al., 2005; Swijnenburg et al., 2005). Pericyte transplantation induces angiogenesis and improves blood flow to ischemic hindlimbs in animal models (He et al., 2010; Dar et al., 2012), and based on their role in forming and stabilizing engineered blood vessels, they have been proposed for angiogenic therapy. Surprisingly, not all pericytes can induce angiogenesis. Only type- 2 has angiogenic potential in vitro, and, in vivo, angiogenesis occurs when type2 , but not type-1, pericytes are injected with endothelial cells in a Matrigel plug (Birbrair et al., 2014). Type-2 can also recover blood flow in a mouse model of hindlimb ischemia (Birbrair et al., 2014), but the mechanism remains to be elucidated (Birbrair et al., 2014). Due to the short recovery time, the femoral artery is probably rebuilt by anastomoses of the proximal stump with new collateral blood vessels after intramuscular pericyte injection (Schaper and Scholz, 2003).

Pericyte subtypes in human skeletal muscle have not yet been identified and isolated, and whether their angiogenic potential differs remains unknown.

To study the physiological roles of different cell populations, genetic strategies to ablate specific cell types have been developed. Several transgenic mice now provide effective means to genetically ablate pericytes (Cooke et al., 2012; Lebleu et al., 2013), satellite cells (Dellavalle et al., 2011; Lepper et al., 2011; McCarthy et al., 2011), fibroblasts (Barnes and Glass, 2011), and macrophages (Ferenbach et al., 2012; Weisser et al., 2012) for a defined period. These studies will elucidate the exact role of each cell population in inducing and regulating skeletal muscle angiogenesis. For example, to determine whether endogenous pericytes are necessary for skeletal muscle angiogenesis after ischemia, transgenic mice with pericyte depletion, such as NG2-tk (Cooke et al., 2012; Lebleu et al., 2013), should be examined. Cell ablation studies must consider that besides pericytes, oligodendrocyte progenitors express NG2 (Encinas et al., 2011).

Understanding the molecular mechanisms of ischemia induced endogenous angiogenesis is critical. Genetically modified mice have been widely applied to study the signals required for postnatal hindlimb angiogenesis. Knockout mice allowed several groups to test whether such signals are necessary for skeletal muscle angiogenesis. Neovascularization of impaired ischemic limbs was found in mice deficient in angiotensin II type-1 receptor (Sasaki et al., 2002), endothelial-derived nitric oxide synthase (eNOS; Murohara et al., 1998), matrix metalloproteinase-9 (Johnson et al., 2004), caveolin-1 (Sonveaux et al., 2004), adiponectin (Shibata et al., 2004), PlGF (Carmeliet et al., 2001), and IL-10 (Silvestre et al., 2000). Are these molecules expressed in pericytes? The specific cell types essential to angiogenesis after hindlimb ischemia remain unclear. In addition, analysis of global knockout mutant mice is complicated by unrelated side effects in other tissues, which can be avoided only by performing conditional mutagenesis. When investigators can control the timing and location of somatic mutations in adult mice, they will be able to determine the roles of specific signaling molecules in different cell populations and the functional consequences of deleting single genes in specific cell types, such as pericytes, during skeletal muscle angiogenesis. The clinical need for interventions in ischemic illnesses leading to revascularization and the encouraging recent findings that pericytes have the potential to improve blood perfusion will stimulate these efforts.

\section{PERICYTES IN SKELETAL MUSCLE FIBROSIS}

Fibrosis is an incompletely understood process characterized by excessive accumulation of extracellular matrix components, such as collagen (Wynn, 2008). It occurs under chronic disease conditions and may affect skeletal muscle (Wynn, 2007). Fibrous tissue may prevent full functional recovery of skeletal muscle (Kasemkijwattana et al., 1998; Kaariainen et al., 2000; Huard et al., 2002; Jarvinen et al., 2005; Gharaibeh et al., 2012), which, under normal conditions, can repair itself after injury. Fibrosis 
directly contributes to progressive skeletal muscle dysfunction in several chronic diseases, such as Duchenne muscular dystrophy (Mann et al., 2011; Brandan and Gutierrez, 2013; Morales et al., 2013; Acuna et al., 2014); and its treatment is currently considered important for muscular dystrophies. Furthermore, one of the causes of age-related skeletal muscle stiffness, weakness, and atrophy is increased infiltration of fibrous tissue (Ryall et al., 2008; Thompson, 2009; Kragstrup et al., 2011; Walston, 2012). The regenerative potential of muscle stem cells is limited by the formation of fibrous tissue, which lacks innervation and contractile properties (Juhas and Bursac, 2013). Studies performed in mouse models clearly associate skeletal muscle fibrosis with aging (Goldspink et al., 1994; Huard et al., 2002; Jarvinen et al., 2002; Brack et al., 2007; Zhu et al., 2007; Graham et al., 2010; Trensz et al., 2010). Understanding the cellular and molecular mechanisms underlying skeletal muscle fibrosis is essential to developing effective antifibrotic therapies.

While collagen accumulation is a major feature of skeletal muscle fibrosis (Mohan and Radha, 1980; Alnaqeeb et al., 1984; Goldspink et al., 1994; Haus et al., 2007; Kragstrup et al., 2011), the source of the collagen-producing cells in various conditions is less clear. Many have been proposed, including resident fibroblasts (Thiery et al., 2009; Lieber and Ward, 2013), muscle-derived stem cells ( $\mathrm{Li}$ and Huard, 2002), myoblasts (Li et al., 2004; Alexakis et al., 2007), endothelial cells (Zeisberg et al., 2007), pericytes (Birbrair et al., 2013d), fibroadipogenic progenitors (FAPs; Joe et al., 2010; Uezumi et al., 2011), fibrocytes (Herzog and Bucala, 2010), and even nerve-associated cells (Hinz et al., 2012). However, the exact role of these cells in skeletal muscle fibrosis is unclear, and the origin of collagen-producing cells has not been confirmed using the same methodologies (in vitro or in vivo). Furthermore, skeletal muscle fibrosis induced in different ways may recruit different cell populations. For instance, some fibrosis mouse models are reversible, and collagen production may be part of the repair process. Given the large number of possible cell sources, future studies will have to use modern molecular techniques, such as fate-mapping, to create strategies to reverse skeletal muscle fibrosis.

Chronic activation of PDGFR $\alpha$ results in widespread organ fibrosis (Olson and Soriano, 2009), indicating that PDGFR $\alpha+$ cells may have a role in skeletal muscle fibrosis. Type-1 pericytes and FAPs express this receptor (Joe et al., 2010; Uezumi et al., 2010, 2011; Birbrair et al., 2013a), and like pericytes, FAPs line the skeletal muscle vasculature (Joe et al., 2010), suggesting their roles may overlap (Birbrair et al., 2013a). The extent of perivascular PDGFR $\alpha+$ cells' contribution to skeletal muscle fibrosis has not been demonstrated. Future studies should use fate-mapping of endogenous skeletal muscle PDGFR $\alpha+$ cells exposed to distinct conditions leading to fibrosis. Determining whether PDGFR $\alpha+$ pericytes and PDGFR $\alpha+$ FAPs are lineagerelated and whether their roles in skeletal muscle fibrosis vary would also be interesting.

As with $\operatorname{PDGFR} \alpha$, the selective overexpression of a disintegrin and metalloprotease 12 (ADAM12) in the skeletal muscle increases fibrosis and suppresses regeneration (Jorgensen et al., 2007). In an elegant study, researchers used an inducible, tetracycline-dependent, cell-fate mapping system. They generated triple transgenic mice that expressed tetracycline transactivator under control of the ADAM12 locus, the conditional reporter RosaYFP, and the recombinase Cre under control of the tetracycline transactivator. Labeling the cells derived from ADAM12+ cells was temporally controlled by administering doxycycline, which prevents Cre expression, and they inducibled genetic ablation of ADAM12+ cells in the skeletal muscle. Their findings revealed that pericytes expressing ADAM12 during development, located in very close proximity to blood vessel endothelial cells, give rise to most of the collagen-producing cells during skeletal muscle injury (Dulauroy et al., 2012). However, fibrosis formation was analyzed in healthy, young skeletal muscle after injury. Future studies should explore whether the collagen-producing cells in the skeletal muscle of $\mathrm{mdx}$ and old mice have the same ancestors.

A new finding complements the evidence that pericytes are the source of collagen-producing cells in the fibrous tissue deposited in old skeletal muscle. Birbrair et al. (2013d) found that the pericytes involved in scar formation in the skeletal muscle of old mice differ from those associated with skeletal muscle regeneration; only type-1 pericytes contribute (Birbrair et al., 2013d). Future studies should use this pericyte subpopulation as a cellular target to reduce fibrosis in older mammals.

The cellular source of fibrosis in chronic diseases, such as Duchenne muscular dystrophy, remains unknown. To what extent type-1 pericytes contribute to collagen-producing cells in the skeletal muscle in comparison with other cell populations that give rise to those cells is also unclear. The detailed fate-mapping and lineage-tracing experiments that confirm pericyte participation in skeletal muscle fibrosis have not been done for other possible cellular sources of collagen-producing cells.

The basic molecular mechanisms involved in fibrous tissue deposition in the skeletal muscle are not completely understood. The well-studied cytokine transforming growth factor $\beta$ (TGF $\beta$ ), which is released from injured myofibers, seems to be essential to fibrous tissue formation (Massague, 2012). It binds to transmembrane receptor TGF $\beta$ receptor type II, recruiting TGF $\beta$ receptor type I to the complex. Both receptors have serine/threonine kinase activity and form heteromeric complexes in the presence of the activated ligand. TGF $\beta$ binding to the extracellular domains of type I and type II receptors initiates signaling cascades across the cell membrane by inducing transphosphorylation. It subsequently activates the type I receptor at the glycine/serine (GS)-rich domain, which acts as a phosphorylation site with receptor kinase activity (Kang et al., 2009). The type 1 receptor then catalyzes activation of the intracellular SMAD transcription factors (Massague et al., 2005), which stimulate transcription of specific target genes, leading to the production of extracellular matrix proteins and fibrosis formation (Lieber and Ward, 2013) that interfere with skeletal muscle regeneration and function (Gharaibeh et al., 2012). In contrast, inhibiting TGF $\beta$ reduces fibrosis and promotes muscle regeneration (Fukushima et al., 2001; Sato et al., 2003).

TGF $\beta$ is involved in a range of biological processes (Heldin et al., 2009; Padua and Massague, 2009; Hawinkels and Ten Dijke, 2011; Dooley and Ten Dijke, 2012; Pardali and Ten Dijke, 2012). Thus, detailed understanding of which cells respond to 
its signaling is required for the design of effective therapeutic approaches without undesirable side effects. At least in vitro, type- 1 pericytes respond to TGF $\beta$, increasing type I collagen production (Birbrair et al., 2013d), while type-2 did not seem to respond under the same conditions (Birbrair et al., 2013d). Future experiments should test whether TGF $\beta$ signaling is required for pericytes to participate in skeletal muscle scarring in vivo. One indication for this requirement is that TGF $\beta$ induces ADAM12 expression (Solomon et al., 2010; Dulauroy et al., 2012), which plays an important role in pericytes' fibrotic response.

Another member of the TGF $\beta$ protein superfamily, myostatin (McPherron et al., 1997), also known as GDF-8, not only controls skeletal muscle growth, but also regulates the progression of fibrosis (Li et al., 2008). Connective tissue growth factor (CTGF) is another molecule that has been shown to reproduce many of the profibrotic effects of TGF $\beta$ in skeletal muscle. Elevated levels of CTGF have been detected in skeletal muscle from mdx mice, dystrophic dogs, and patients with Duchenne muscular dystrophy (Sun et al., 2008; Vial et al., 2008). Whether pericytes express receptors and respond to myostatin and CTGF has yet to be explored. TGF $\beta$ can also induce production of PDGFs (Bonner, 2004). As pericytes express receptors to these ligands (Hellstrom et al., 1999), whether this signaling pathway plays a role in skeletal muscle fibrosis in vivo should be explored. Fibroblasts that express MMP9 and PlGF help to recover the vascular network structure by diminishing collagen deposition in the skeletal muscle of old dystrophic mice (Gargioli et al., 2008). Whether the expression of these factors differs between the two pericyte subtypes is unknown.

For full functional recovery of skeletal muscle affected by chronic diseases, aging, and trauma, fibrosis must be limited. Effective repair of skeletal muscle under these conditions cannot be achieved yet. More studies are needed to define the cellular and molecular mechanisms and functional significance of fibrosis in healthy, young and diseased, old skeletal muscles. Although pericytes play an important role in this process, detailed fate-mapping and lineage-tracing experiments would significantly advance the field.

\section{PERICYTE CONTRIBUTION TO FAT ACCUMULATION IN SKELETAL MUSCLE}

Accumulation of ectopic adipocytes in skeletal muscle is typical of such disorders as obesity, sarcopenia, and dystrophies and provides an accurate assessment of the severity of Duchenne muscular dystrophy (DMD) (Wren et al., 2008). Increased fat is also observed in the skeletal muscle of older adults (Goodpaster et al., 2004; Goodpaster and Wolf, 2004; Visser et al., 2005).

The origin of these fat cells has been revealed only recently. A group of cells in the perimysium, particularly the perivascular space (Greco et al., 2002), where fat accumulation is most evident, express platelet-derived growth factor receptor $\alpha$ (PDGFR $\alpha)$, the major contributor to ectopic fat cell formation in skeletal muscle. These cells are quiescent in intact muscle but proliferate efficiently in response to damage. PDGFR $\alpha+$ cells differ from satellite cells and are located in the muscle interstitial space between myofibers, close to blood vessels (Joe et al., 2010; Rodeheffer, 2010; Uezumi et al., 2010). Skeletal muscle pericytes can differentiate in vitro toward adipogenic lineage (Farrington-Rock et al., 2004; Crisan et al., 2008a) but, like PDGFR $\alpha+$ cells, do not generate myofibers, and only type- 1 express PDGFR $\alpha$. When purified type- 1 pericytes are delivered intramuscularly in a mouse model of fatty infiltration, ectopic white fat is generated (Birbrair et al., 2013a). This approach clearly identifies their adipogenic potential, but only lineage-tracing will demonstrate that type-1 pericytes become fat cells in skeletal muscle in vivo under physiological conditions.

Whether perivascular PDGFR $\alpha+$ cells have a physiological role in the various illnesses characterized by muscular ectopic fat accumulation, such as myopathies and obesity, and whether modifying cell properties by manipulation and grafting would influence their fate in vivo are unclear. Although genetic tracing techniques were used to track these cells in other tissues (Lee and Granneman, 2012), confirming their capacity to become fat cells in skeletal muscle will require lineage-tracing studies. Testing whether depleting specific PDGFR $\alpha+$ perivascular cells would prevent fat formation in skeletal muscle would also be interesting.

Is activating PDGFR $\alpha$ important for the adipogenetic role of PDGFR $\alpha+$ perivascular cells in skeletal muscle? Most of the primary functions of PDGF $\alpha$ and platelet-derived growth factor receptor $\alpha(\operatorname{PDGFR} \alpha)$, were unknown because Pdgfa and Pdgfra knockout mice die either as embryos or shortly after birth. Recent experiments using conditional gene ablation and gain-offunction transgenics (Gnessi et al., 1993; Bostrom et al., 1996; Soriano, 1997; Fruttiger et al., 1999; Karlsson et al., 1999, 2000) showed that PDGF $\alpha$ receptors are crucial for the proper development of several tissues (Crosby et al., 1998; Bostrom et al., 2002; Ostman, 2004). After ligand binding, the kinase domains of $\operatorname{PDGFR} \alpha$ phosphorylate tyrosine residues of the receptor's cytoplasmic domain, which act as docking sites for phosphatidylinositol 3-kinase, STATs, SRC family kinases, SHP2 phosphatase, and phospholipase C $\gamma$ (Vignais and Gilman, 1999; Lakner et al., 2010; Xiong et al., 2010; Lin et al., 2014). These pathways regulate such transcription factors as SREBP, FOXO, c-MYC, and AP1, which are involved in cell growth, proliferation, differentiation, survival, and migration (Besancon et al., 1998; Tsatsanis and Spandidos, 2000; Guida et al., 2007; Erovic et al., 2012). They have also been linked to diseases characterized by fat accumulation in blood vessel walls, such as atherosclerosis (Tedgui and Mallat, 2006; Artwohl et al., 2009; Feinberg, 2013; Li et al., 2013). However, the function of PDGF $\alpha$ ligands and their receptors in skeletal muscle adipogenesis remains unclear. The pericyte marker neural/glial antigen 2 (NG2) proteoglycan (Ozerdem et al., 2001) binds to PDGF $\alpha$ (Goretzki et al., 2000) and may function as its co-receptor with a potential effect on the respective cell-surface signaling receptor (PDGFR $\alpha$ ) (Grako and Stallcup, 1995; Grako et al., 1999). Future studies may determine whether the fate of PDGFR $\alpha+$ pericytes changes when they are exposed to PDGF $\alpha$ and whether their differentiation potential remains unchanged after exposure to PDGFR $\alpha$-Fc chimeric receptors, which compete with their receptors for ligands in vitro. Loss-of-function and gain-of-function assays may demonstrate whether PDGFR $\alpha$ in pericytes regulates fat formation in skeletal muscle.

Systemic factors, such as hormone levels and nutrients, may play a role in regulating PDGFR $\alpha+$ cells' adipogenic potential. For instance, a high-glucose medium was reported to 
enhance adipogenic differentiation of skeletal muscle-derived cells (Aguiari et al., 2008), suggesting that the microenvironment may determine the fate of cells that sense changes in skeletal muscle physiology. The ability to target skeletal muscle PDGFR $\alpha+$ perivascular cells exclusively will open new therapeutic strategies for skeletal muscle diseases caused by, or associated with, severe adipose tissue accumulation.

Pericyte participation in fat infiltration of skeletal muscle has been confirmed (Birbrair et al., 2013a), providing a cellular target susceptible to pharmacological modulation and signaling manipulation. This strategy will require more detailed analyses.

\section{PERICYTES AND ECTOPIC BONE FORMATION IN SKELETAL MUSCLE}

Heterotopic ossification, the ectopic formation of bone and/or cartilage in soft tissues, such as skeletal muscles outside the periosteum, happens only in genetic disorders, such as fibrodysplasia ossificans progressiva and progressive osseous heteroplasia (Adegbite et al., 2008; Yu et al., 2008; Kaplan et al., 2012). In the skeletal muscles of $\mathrm{mdx}$ mice (dystrophin-deficient mouse model of Duchenne muscular dystrophy) (Kikkawa et al., 2009; Mu et al., 2013), this debilitating condition may be induced by the inflammation associated with trauma. However, other causes have been reported (Thorseth, 1968; Sirvanci et al., 2004; McCulloch and Bush-Joseph, 2006; Bek et al., 2009; Kim and Choi, 2009; Chouhan et al., 2012; Kalenderer et al., 2012).

The biological mechanism leading to osteoinduction in the skeletal muscle under physiological conditions has not been identified, and the exact cellular origin of heterotopic ossification is not well characterized. Nevertheless, recent sophisticated studies have made advances. The use of Cre/loxP technology allows investigators to track specific cell lineages (Liu et al., 2004; Maes et al., 2010). Several studies used murine models harboring real-time visual transgenes and Cre/loxP technology as a powerful way to identify which cells in skeletal muscle give rise to bone-forming cells (Kan et al., 2009, 2013; Lounev et al., 2009; Medici et al., 2010; Chakkalakal et al., 2012). Injury may provoke a local inflammatory reaction, and cytokines released into the blood might prompt circulating immune cells to differentiate into osteoblasts. However, using CD19-Cre, LCK-Cre, and Lyz-Cre transgenic mice, researchers have shown that B cells, $T$ cells, and macrophages/monocytes, respectively, do not generate them (Kan et al., 2009). Somite-derived cells were excluded using Nestin-Cre reporter mice, and myoblasts, which are more committed to the myogenic lineage, were excluded using Myf5-Cre (Kan et al., 2009) and MyoD-Cre (Lounev et al., 2009) transgenic mice. These results are consistent with the fact that, during the generation of ectopic bone, the early immune response in skeletal muscle lesions kills myoblasts (Shore and Kaplan, 2010).

Recent investigations have suggested that cells residing in the skeletal muscle interstitial space contribute to some of the ectopic bone tissue (Wosczyna et al., 2012). However, their precise identity was not determined (Bosch et al., 2000). Histological analyses of heterotopic lesions from patients with fibrodysplasia ossificans progressiva demonstrate positive staining for endothelial markers, such as the angiopoietin receptor, Tie2, in ectopic chondrocytes and osteoblasts, suggesting a possible role for endothelial cells (Lounev et al., 2009; Medici et al., 2010). However, this marker is not specific to endothelial cells; in fact, it is also expressed in pericytes (Park et al., 2003; Cai et al., 2008). Cells expressing Tie2 receptor respond to inflammatory triggers, differentiate into osteogenic lineage, and contribute greatly to heterotopic bone in animal models of fibrodysplasia ossificans progressiva (Lounev et al., 2009; Wosczyna et al., 2012). Lineagetracing studies using Tie2-Cre reporter mice have also pointed to these cells in generating the chondrocytes and osteoblasts found in skeletal muscle lesions (Lounev et al., 2009; Medici et al., 2010; Chakkalakal et al., 2012). Other analyses revealed that skeletal muscle osteogenic progenitors, distinct from satellite cells, express PDGFR $\alpha$ (Oishi et al., 2013). They undergo osteogenic differentiation both in vitro and in vivo in response to osteogenic conditions and/or BMP stimuli (Uezumi et al., 2010; Oishi et al., 2013) and have been observed surrounding ectopic bone tissues after trauma in humans. In skeletal muscle, PDGFR $\alpha+$ cells accumulate around blood vessels (Uezumi et al., 2014) and include type-1 pericytes (Birbrair et al., 2013a), suggesting that a pericyte subpopulation may also form ectopic bone in skeletal muscle. Blood vessels could be a source of osteogenic progenitor cells, which differentiate into osteoblasts, for example, when inflammatory cytokines are released by macrophages. However, this hypothesis has not been tested experimentally.

Skeletal muscle pericytes have chondrogenic potential in vitro (Crisan et al., 2008a), and Li et al. (2011) showed that cells residing in the skeletal muscle fascia have strong chondrogenic potential but lack pericyte marker CD146. Crisan et al. (2008b) also reported that vascular pericytes may differentiate into osteoblasts. Levy et al. (2001) and other groups suggested a similarity between osteoprogenitors in the skeletal muscle and pericytes isolated from intramuscular connective tissue (Diaz-Flores et al., 1992a; Gronthos and Simmons, 1996; Reilly et al., 1998; Kuznetsov et al., 2001; Levy et al., 2001; Crisan et al., 2008a). Whether they contribute to the heterotopic ossification that occurs in skeletal muscle in vivo is not known Although in bone marrow pericytes are capable of bone formation (Shi and Gronthos, 2003; Sacchetti et al., 2007; Mendez-Ferrer et al., 2010b), their characteristics may vary significantly between tissues (Armulik et al., 2011).

A recent lineage-tracing study using GLAST-CreER mice identified GLAST-expressing cells as precursors that contribute to heterotopic ossification (Kan et al., 2013). GLAST (glutamate aspartate transporter) is expressed in various central nervous system (CNS) cells, such as Muller, Bergmann glia, astrocyte, and neural stem cells (Danbolt et al., 1992; Levy et al., 1993; Lehre et al., 1995; Shibata et al., 1997; Izumi et al., 2002; Slezak et al., 2007; Ehm et al., 2010), but can also be found in other cell types, such as pericytes in the spinal cord (Goritz et al., 2011). Whether GLAST is expressed in cells outside the CNS is not known, and verifying whether skeletal muscle pericytes express GLAST would be especially interesting. Supporting this idea, most GLAST-creER labeled cells in skeletal muscle interstitium were closely associated with vasculature (Kan et al., 2013). This study did not specify the cellular origin, but approximately $35 \%$ of the ectopic bone-producing cells in the lesions clearly belong to a GLAST-expressing lineage. Is a specific pericyte subpopulation responsible? What is its contribution compared to other cell 
types'? The possibility that osteoprogenitor cells might originate from perivascular cells highlights the strong association between angiogenesis and the heterotypic ossification of skeletal muscle (Hegyi et al., 2003).

The basic molecular mechanisms involved in ectopic calcification in skeletal muscle are not known. Critical inductive factors and a permissive environment may affect specific cell types and contribute to heterotopic ossification (Chalmers et al., 1975; Baird and Kang, 2009). A recent study suggests that the same mechanism that induces vascular calcification gives rise to osteoprogenitor cells (Yao et al., 2013). Elucidating these mechanisms is important since we have no effective and safe therapy to prevent this condition. Regulatory molecules acting on the perivascular cells necessary for the development of traumatic heterotopic ossification should be further investigated.

The bone morphogenetic proteins (BMP) of ALK2 ligands, such as BMP2, BMP4, and BMP9, might be primary inducers of heterotopic ossification; mixed with Matrigel and injected into the skeletal muscles of mice, they have osteoblastic activity (Chen et al., 2012; Nishimura et al., 2012), and they are highly expressed in human lesions with heterotopic ossification (Gannon et al., 1997; Grenier et al., 2013). Transgenic mouse models of heterotopic ossification with specific signaling molecules, such as BMPs, deleted should be used in different cellular targets to verify whether those molecules are essential for in vivo ectopic bone formation in skeletal muscle in physiological conditions. Future studies should determine whether BMP receptors are expressed in pericytes. Additionally, the fate of pericyte subtypes exposed to BMPs should be investigated to determine whether their differentiation potential remains unchanged after exposure to BMPR-Fc chimeric receptors, which compete with pericyte receptors for ligands. Future efforts should focus on the activation of osteogenic potential by such less-studied molecules as the growth factor Nell-1, which induces osteogenic differentiation in pericytes (Zhang et al., 2011). The discovery of such signals and a better understanding of the exact role of pericytes in skeletal muscle ectopic calcification would support development of therapeutic strategies to treat this clinically significant condition.

\section{CONCLUSIONS}

Pericytes play several critical roles in skeletal muscle repair, and elucidating how their tissue- formation capabilities contribute to skeletal muscle pathophysiology will be important to future treatments. Based on their molecular markers and specific functions, muscular pericytes have been identified as heterogeneous, and at least two subpopulations have been described. Taking their diversity into account, information regarding pericytes will be crucial in advancing our understanding of skeletal muscle disease and aging.

\section{ACKNOWLEDGMENTS}

Studies cited in the reference list by the authors were supported by a Glenn/AFAR Scholarship for Research in the Biology of Aging to Alexander Birbrair; Wake Forest Pepper Center Pilot Project to Osvaldo Delbono and PUSH grant from the Wake Forest Comprehensive Cancer Center to Akiva Mintz and Osvaldo Delbono; grants from the National Institutes of Health/National
Institute on Aging (AG13934 and AG15820) to Osvaldo Delbono, Wake Forest Claude D. Pepper Older Americans Independence Center (P30-AG21332).

\section{REFERENCES}

Aagaard, P., Suetta, C., Caserotti, P., Magnusson, S. P., and Kjaer, M. (2010). Role of the nervous system in sarcopenia and muscle atrophy with aging: strength training as a countermeasure. Scand. J. Med. Sci. Sports 20, 49-64. doi: 10.1111/j.1600-0838.2009.01084.x

Acharyya, S., Butchbach, M. E., Sahenk, Z., Wang, H., Saji, M., Carathers, M., et al. (2005). Dystrophin glycoprotein complex dysfunction: a regulatory link between muscular dystrophy and cancer cachexia. Cancer Cell 8, 421-432. doi: 10.1016/j.ccr.2005.10.004

Acuna, M. J., Pessina, P., Olguin, H., Cabrera, D., Vio, C. P., Bader, M., et al. (2014). Restoration of muscle strength in dystrophic muscle by angiotensin-17 through inhibition of TGF-beta signalling. Hum. Mol. Genet. 23, 1237-1249. doi: $10.1093 / \mathrm{hmg} / \mathrm{ddt} 514$

Adegbite, N. S., Xu, M., Kaplan, F. S., Shore, E. M., and Pignolo, R. J. (2008). Diagnostic and mutational spectrum of progressive osseous heteroplasia $(\mathrm{POH})$ and other forms of GNAS-based heterotopic ossification. Am. J. Med. Genet. A 146A, 1788-1796. doi: 10.1002/ajmg.a.32346

Aguiari, P., Leo, S., Zavan, B., Vindigni, V., Rimessi, A., Bianchi, K., et al. (2008). High glucose induces adipogenic differentiation of muscle-derived stem cells. Proc. Natl. Acad. Sci. U.S.A. 105, 1226-1231. doi: 10.1073/pnas.07114 02105

Alessandri, G., Pagano, S., Bez, A., Benetti, A., Pozzi, S., Iannolo, G., et al. (2004). Isolation and culture of human muscle-derived stem cells able to differentiate into myogenic and neurogenic cell lineages. Lancet 364, 1872-1883. doi: 10.1016/S0140-6736(04)17443-6

Alexakis, C., Partridge, T., and Bou-Gharios, G. (2007). Implication of the satellite cell in dystrophic muscle fibrosis: a self-perpetuating mechanism of collagen overproduction. Am. J. Physiol. Cell Physiol. 293, C661-C669. doi: 10.1152/ajpcell.00061.2007

Alexander, K. A., Chang, M. K., Maylin, E. R., Kohler, T., Muller, R., Wu, A. C., et al. (2011). Osteal macrophages promote in vivo intramembranous bone healing in a mouse tibial injury model. J. Bone Miner. Res. 26, 1517-1532. doi: 10.1002/jbmr.354

Alnaqeeb, M. A., Al Zaid, N. S., and Goldspink, G. (1984). Connective tissue changes and physical properties of developing and ageing skeletal muscle. J. Anat. 139(Pt 4), 677-689.

Amselgruber, W. M., Schafer, M., and Sinowatz, F. (1999). Angiogenesis in the bovine corpus luteum: an immunocytochemical and ultrastructural study. Anat. Histol. Embryol. 28, 157-166. doi: 10.1046/j.1439-0264.1999.00195.x

Andersen, J. L. (2003). Muscle fibre type adaptation in the elderly human muscle. Scand. J. Med. Sci. Sports 13, 40-47. doi: 10.1034/j.1600-0838.2003.00299.x

Anghelina, M., Krishnan, P., Moldovan, L., and Moldovan, N. I. (2004) Monocytes and macrophages form branched cell columns in matrigel: implications for a role in neovascularization. Stem Cells Dev. 13, 665-676. doi: 10.1089/scd.2004.13.665

Anghelina, M., Krishnan, P., Moldovan, L., and Moldovan, N. I. (2006) Monocytes/macrophages cooperate with progenitor cells during neovascularization and tissue repair: conversion of cell columns into fibrovascular bundles. Am. J. Pathol. 168, 529-541. doi: 10.2353/ajpath.2006.050255

Anghelina, M., Schmeisser, A., Krishnan, P., Moldovan, L., Strasser, R. H., and Moldovan, N. I. (2002). Migration of monocytes/macrophages in vitro and in vivo is accompanied by MMP12-dependent tunnel formation and by neovascularization. Cold Spring Harb. Symp. Quant. Biol. 67, 209-215. doi: 10.1101/ sqb.2002.67.209

Argiles, J. M., Busquets, S., Felipe, A., and Lopez-Soriano, F. J. (2006). Muscle wasting in cancer and ageing: cachexia versus sarcopenia. Adv. Gerontol. 18, 39-54. doi: 10.1007/978-90-481-9713-2_2

Armulik, A., Abramsson, A., and Betsholtz, C. (2005). Endothelial/pericyte interactions. Circ. Res. 97, 512-523. doi: 10.1161/01.RES.0000182903.16652.d7

Armulik, A., Genove, G., and Betsholtz, C. (2011). Pericytes: developmental, physiological, and pathological perspectives, problems, and promises. Dev. Cell 21, 193-215. doi: 10.1016/j.devcel.2011.07.001

Arsic, N., Mamaeva, D., Lamb, N. J., and Fernandez, A. (2008). Muscle-derived stem cells isolated as non-adherent population give rise to cardiac, skeletal 
muscle and neural lineages. Exp. Cell Res. 314, 1266-1280. doi: 10.1016/j.yexcr. 2008.01.009

Artwohl, M., Lindenmair, A., Roden, M., Waldhausl, W. K., Freudenthaler, A., Klosner, G., et al. (2009). Fatty acids induce apoptosis in human smooth muscle cells depending on chain length, saturation, and duration of exposure. Atherosclerosis 202, 351-362. doi: 10.1016/j.atherosclerosis.2008.05.030

Asakura, A., and Rudnicki, M. A. (2002). Side population cells from diverse adult tissues are capable of in vitro hematopoietic differentiation. Exp. Hematol. 30, 1339-1345. doi: 10.1016/S0301-472X(02)00954-2

Bachrach, E., Li, S., Perez, A. L., Schienda, J., Liadaki, K., Volinski, J., et al. (2004). Systemic delivery of human microdystrophin to regenerating mouse dystrophic muscle by muscle progenitor cells. Proc. Natl. Acad. Sci. U.S.A. 101, 3581-3586. doi: 10.1073/pnas.0400373101

Baird, E. O., and Kang, Q. K. (2009). Prophylaxis of heterotopic ossification - an updated review. J. Orthop. Surg. Res. 4:12. doi: 10.1186/1749-799X-4-12

Balabanov, R., Washington, R., Wagnerova, J., and Dore-Duffy, P. (1996). CNS microvascular pericytes express macrophage-like function, cell surface integrin alpha M, and macrophage marker ED-2. Microvasc. Res. 52, 127-142. doi: 10.1006/mvre.1996.0049

Barbera-Guillem, E., Nyhus, J. K., Wolford, C. C., Friece, C. R., and Sampsel, J. W. (2002). Vascular endothelial growth factor secretion by tumor-infiltrating macrophages essentially supports tumor angiogenesis, and IgG immune complexes potentiate the process. Cancer Res. 62, 7042-7049.

Barnes, J. L., and Glass, W. F. 2nd. (2011). Renal interstitial fibrosis: a critical evaluation of the origin of myofibroblasts. Contrib. Nephrol. 169, 73-93. doi: $10.1159 / 000313946$

Batt, J., Bain, J., Goncalves, J., Michalski, B., Plant, P., Fahnestock, M., et al. (2006). Differential gene expression profiling of short and long term denervated muscle. FASEB J. 20, 115-117. doi: 10.1096/fj.04-3640fje

Baumgartner, I., Schainfeld, R., and Graziani, L. (2005). Management of peripheral vascular disease. Annu. Rev. Med. 56, 249-272. doi: 10.1146/annurev.med.56. 082103.104649

Behnke, B. J., Prisby, R. D., Lesniewski, L. A., Donato, A. J., Olin, H. M., and Delp, M. D. (2006). Influence of ageing and physical activity on vascular morphology in rat skeletal muscle. J. Physiol. 575, 617-626. doi: 10.1113/jphysiol.2006.108431

Beitzel, F., Gregorevic, P., Ryall, J. G., Plant, D. R., Sillence, M. N., and Lynch, G. S. (2004). Beta2-adrenoceptor agonist fenoterol enhances functional repair of regenerating rat skeletal muscle after injury. J. Appl. Physiol. 96, 1385-1392. doi: 10.1152/japplphysiol.01081.2003

Bek, D., Beksac, B., Della Valle, A. G., Sculco, T. P., and Salvati, E. A. (2009). Aspirin decreases the prevalence and severity of heterotopic ossification after 1-stage bilateral total hip arthroplasty for osteoarthrosis. J. Arthroplasty 24, 226-232. doi: 10.1016/j.arth.2007.11.008

Benjamin, L. E., Golijanin, D., Itin, A., Pode, D., and Keshet, E. (1999). Selective ablation of immature blood vessels in established human tumors follows vascular endothelial growth factor withdrawal. J. Clin. Invest. 103, 159-165. doi: 10.1172/JCI5028

Benjamin, L. E., Hemo, I., and Keshet, E. (1998). A plasticity window for blood vessel remodelling is defined by pericyte coverage of the preformed endothelial network and is regulated by PDGF-B and VEGF. Development 125, 1591-1598.

Bentzinger, C. F., and Rudnicki, M. A. (2014). Rejuvenating aged muscle stem cells. Nat. Med. 20, 234-235. doi: 10.1038/nm.3499

Berardi, E., Annibali, D., Cassano, M., Crippa, S., and Sampaolesi, M. (2014). Molecular and cell-based therapies for muscle degenerations: a road under construction. Front. Physiol. 5:119. doi: 10.3389/fphys.2014.00119

Bergers, G., and Song, S. (2005). The role of pericytes in blood-vessel formation and maintenance. Neuro-oncology 7, 452-464. doi: 10.1215/S1152851705000232

Bergwerff, M., Verberne, M. E., Deruiter, M. C., Poelmann, R. E., and GittenbergerDe Groot, A. C. (1998). Neural crest cell contribution to the developing circulatory system: implications for vascular morphology? Circ. Res. 82, 221-231. doi: 10.1161/01.RES.82.2.221

Bernet, J. D., Doles, J. D., Hall, J. K., Kelly Tanaka, K., Carter, T. A., and Olwin, B. B. (2014). p38 MAPK signaling underlies a cell-autonomous loss of stem cell self-renewal in skeletal muscle of aged mice. Nat. Med. 20, 265-271. doi: 10.1038/nm.3465

Besancon, F., Atfi, A., Gespach, C., Cayre, Y. E., and Bourgeade, M. F. (1998). Evidence for a role of NF-kappaB in the survival of hematopoietic cells mediated by interleukin 3 and the oncogenic TEL/platelet-derived growth factor receptor beta fusion protein. Proc. Natl. Acad. Sci. U.S.A. 95, 8081-8086. doi: 10.1073/pnas.95.14.8081

Birbrair, A., Wang, Z. M., Messi, M. L., Enikolopov, G. N., and Delbono, O. (2011). Nestin-GFP transgene reveals neural precursor cells in adult skeletal muscle. PLoS ONE 6:e16816. doi: 10.1371/journal.pone.0016816

Birbrair, A., Zhang, T., Wang, Z. M., Messi, M. L., Enikolopov, G. N., Mintz, A., et al. (2013a). Role of pericytes in skeletal muscle regeneration and fat accumulation. Stem Cells Dev. 22, 2298-2314. doi: 10.1089/scd.2012.0647

Birbrair, A., Zhang, T., Wang, Z. M., Messi, M. L., Enikolopov, G. N., Mintz, A., et al. (2013b). Skeletal muscle neural progenitor cells exhibit properties of NG2glia. Exp. Cell Res. 319, 45-63. doi: 10.1016/j.yexcr.2012.09.008

Birbrair, A., Zhang, T., Wang, Z. M., Messi, M. L., Enikolopov, G. N., Mintz, A., et al. (2013c). Skeletal muscle pericyte subtypes differ in their differentiation potential. Stem Cell Res. 10, 67-84. doi: 10.1016/j.scr.2012.09.003

Birbrair, A., Zhang, T., Wang, Z. M., Messi, M. L., Mintz, A., and Delbono, O. (2013d). Type-1 pericytes participate in fibrous tissue deposition in aged skeletal muscle. Am. J. Physiol,. Cell Physiol. 305, C1098-C1113. doi: 10.1152/ajpcell.00171.2013

Birbrair, A., Zhang, T., Wang, Z. M., Messi, M. L., Mintz, A., and Delbono, O. (2015). Pericytes at the intersection between tissue regeneration and pathology. Clin. Sci. 128, 81-93. doi: 10.1042/cs20140278

Birbrair, A., Zhang, T., Wang, Z. M., Messi, M. L., Olson, J. D., Mintz, A., et al. (2014). Type-2 pericytes participate in normal and tumoral angiogenesis. Am. J. Physiol. Cell Physiol. 307, C25-C38. doi: 10.1152/ajpcell.00084.2014

Blaisdell, F. W. (2002). The pathophysiology of skeletal muscle ischemia and the reperfusion syndrome: a review. Cardiovasc. Surg. 10, 620-630. doi: 10.1016/S0967-2109(02)00070-4

Boldrin, L., and Morgan, J. E. (2013). Modulation of the host skeletal muscle niche for donor satellite cell grafting. Methods Mol. Biol. 1035, 179-190. doi: 10.1007/978-1-62703-508-8_15

Bonaldo, P., and Sandri, M. (2013). Cellular and molecular mechanisms of muscle atrophy. Dis. Model. Mech. 6, 25-39. doi: 10.1242/dmm.010389

Bondjers, C., He, L., Takemoto, M., Norlin, J., Asker, N., Hellstrom, M., et al. (2006). Microarray analysis of blood microvessels from PDGF-B and PDGFRbeta mutant mice identifies novel markers for brain pericytes. FASEB J. 20, 1703-1705. doi: 10.1096/fj.05-4944fje

Bonkowski, D., Katyshev, V., Balabanov, R. D., Borisov, A., and Dore-Duffy, P. (2011). The CNS microvascular pericyte: pericyte-astrocyte crosstalk in the regulation of tissue survival. Fluids Barriers CNS 8, 8. doi: 10.1186/2045-8118-8-8

Bonner, J. C. (2004). Regulation of PDGF and its receptors in fibrotic diseases. Cytokine Growth Factor Rev. 15, 255-273. doi: 10.1016/j.cytogfr.2004. 03.006

Booth, F. W., and Thomason, D. B. (1991). Molecular and cellular adaptation of muscle in response to exercise: perspectives of various models. Physiol. Rev. 71, 541-585.

Boppart, M. D., De Lisio, M., Zou, K., and Huntsman, H. D. (2013). Defining a role for non-satellite stem cells in the regulation of muscle repair following exercise. Front. Physiol. 4:310. doi: 10.3389/fphys.2013.00310

Bosch, P., Musgrave, D. S., Lee, J. Y., Cummins, J., Shuler, T., Ghivizzani, T. C., et al. (2000). Osteoprogenitor cells within skeletal muscle. J. Orthop. Res. 18, 933-944. doi: 10.1002/jor.1100180613

Bostrom, H., Gritli-Linde, A., and Betsholtz, C. (2002). PDGF-A/PDGF alphareceptor signaling is required for lung growth and the formation of alveoli but not for early lung branching morphogenesis. Dev. Dyn. 223, 155-162. doi: 10.1002/dvdy. 1225

Bostrom, H., Willetts, K., Pekny, M., Leveen, P., Lindahl, P., Hedstrand, H., et al. (1996). PDGF-A signaling is a critical event in lung alveolar myofibroblast development and alveogenesis. Cell 85, 863-873. doi: 10.1016/S0092-8674(00) 81270-2

Brack, A. S., Conboy, M. J., Roy, S., Lee, M., Kuo, C. J., Keller, C., et al. (2007). Increased Wnt signaling during aging alters muscle stem cell fate and increases fibrosis. Science 317, 807-810. doi: 10.1126/science.1144090

Brandan, E., and Gutierrez, J. (2013). Role of proteoglycans in the regulation of the skeletal muscle fibrotic response. FEBS J. 280, 4109-4117. doi: $10.1111 /$ febs. 12278

Brown, E. B., Campbell, R. B., Tsuzuki, Y., Xu, L., Carmeliet, P., Fukumura, D., et al. (2001). In vivo measurement of gene expression, angiogenesis and physiological function in tumors using multiphoton laser scanning microscopy. Nat. Med. 7, 864-868. doi: 10.1038/89997 
Brushart, T. M., Aspalter, M., Griffin, J. W., Redett, R., Hameed, H., Zhou, C., et al. (2013). Schwann cell phenotype is regulated by axon modality and central-peripheral location, and persists in vitro. Exp. Neurol. 247, 272-281. doi: 10.1016/j.expneurol.2013.05.007

Burger, P. C., and Klintworth, G. K. (1981). Autoradiographic study of corneal neovascularization induced by chemical cautery. Lab. Invest. 45, 328-335.

Caduff, J. H., Fischer, L. C., and Burri, P. H. (1986). Scanning electron microscope study of the developing microvasculature in the postnatal rat lung. Anat. Rec. 216, 154-164. doi: 10.1002/ar.1092160207

Cai, J., Kehoe, O., Smith, G. M., Hykin, P., and Boulton, M. E. (2008). The angiopoietin/Tie-2 system regulates pericyte survival and recruitment in diabetic retinopathy. Invest. Ophthalmol. Vis. Sci. 49, 2163-2171. doi: 10.1167/iovs.07-1206

Carmeliet, P., Moons, L., Luttun, A., Vincenti, V., Compernolle, V., De Mol, M., et al. (2001). Synergism between vascular endothelial growth factor and placental growth factor contributes to angiogenesis and plasma extravasation in pathological conditions. Nat. Med. 7, 575-583. doi: 10.1038/87904

Cavallo, T., Sade, R., Folkman, J., and Cotran, R. S. (1972). Tumor angiogenesis. Rapid induction of endothelial mitoses demonstrated by autoradiography. J. Cell Biol. 54, 408-420. doi: 10.1083/jcb.54.2.408

Cavallo, T., Sade, R., Folkman, J., and Cotran, R. S. (1973). Ultrastructural autoradiographic studies of the early vasoproliferative response in tumor angiogenesis. Am. J. Pathol. 70, 345-362.

Chai, R. J., Vukovic, J., Dunlop, S., Grounds, M. D., and Shavlakadze, T. (2011). Striking denervation of neuromuscular junctions without lumbar motoneuron loss in geriatric mouse muscle. PLoS ONE 6:e28090. doi: 10.1371/journal.pone.0028090

Chakkalakal, S. A., Zhang, D., Culbert, A. L., Convente, M. R., Caron, R. J., Wright, A. C., et al. (2012). An Acvr1 R206H knock-in mouse has fibrodysplasia ossificans progressiva. J. Bone Miner. Res. 27, 1746-1756. doi: 10.1002/jbmr.1637

Chalmers, J., Gray, D. H., and Rush, J. (1975). Observations on the induction of bone in soft tissues. J. Bone Joint Surg. Br. 57, 36-45.

Charge, S. B., and Rudnicki, M. A. (2004). Cellular and molecular regulation of muscle regeneration. Physiol. Rev. 84, 209-238. doi: 10.1152/physrev.00019.2003

Chen, G., Deng, C., and Li, Y. P. (2012). TGF-beta and BMP signaling in osteoblast differentiation and bone formation. Int. J. Biol. Sci. 8, 272-288. doi: 10.7150/ijbs.2929

Chen, Z. L., Yu, W. M., and Strickland, S. (2007). Peripheral regeneration. Annu. Rev. Neurosci. 30, 209-233. doi: 10.1146/annurev.neuro.30.051606.094337

Chi, Y. W., Osinbowale, O., and Milani, R. (2011). Genetic association studies in peripheral arterial disease. J. La. State Med. Soc. 163, 30-34, 36-37, 39.

Chouhan, D. K., Dhillon, M., Bachhal, V., and Prabhakar, S. (2012). Atraumatic heterotopic ossification of iliopsoas muscle: a case report. Orthop. Surg. 4, 197-201. doi: 10.1111/j.1757-7861.2012.00183.x

Conley, K. E., Jubrias, S. A., and Esselman, P. C. (2000). Oxidative capacity and ageing in human muscle. J. Physiol. (Lond). 526 (pt 1), 203-210. doi: 10.1111/j.1469-7793.2000.t01-1-00203.x

Conrad, M. F., Crawford, R. S., Hackney, L. A., Paruchuri, V., Abularrage, C. J., Patel, V. I., et al. (2011). Endovascular management of patients with critical limb ischemia. J. Vasc. Surg. 53, 1020-1025. doi: 10.1016/j.jvs.2010.10.088

Cooke, V. G., Lebleu, V. S., Keskin, D., Khan, Z., O’Connell, J. T., Teng, Y., et al. (2012). Pericyte depletion results in hypoxia-associated epithelial-tomesenchymal transition and metastasis mediated by met signaling pathway. Cancer Cell 21, 66-81. doi: 10.1016/j.ccr.2011.11.024

Cosgrove, B. D., Gilbert, P. M., Porpiglia, E., Mourkioti, F., Lee, S. P., Corbel, S. Y., et al. (2014). Rejuvenation of the muscle stem cell population restores strength to injured aged muscles. Nat. Med. 20, 255-264. doi: 10.1038/nm.3464

Cossu, G., and Biressi, S. (2005). Satellite cells, myoblasts and other occasional myogenic progenitors: possible origin, phenotypic features and role in muscle regeneration. Semin. Cell Dev. Biol. 16, 623-631. doi: 10.1016/j.semcdb.2005.07.003

Crisan, M., Deasy, B., Gavina, M., Zheng, B., Huard, J., Lazzari, L., et al. (2008a). Purification and long-term culture of multipotent progenitor cells affiliated with the walls of human blood vessels: myoendothelial cells and pericytes. Methods Cell Biol. 86, 295-309. doi: 10.1016/S0091-679X(08) 00013-7

Crisan, M., Yap, S., Casteilla, L., Chen, C. W., Corselli, M., Park, T. S., et al. (2008b). A perivascular origin for mesenchymal stem cells in multiple human organs. Cell Stem Cell 3, 301-313. doi: 10.1016/j.stem.2008.07.003
Crosby, J. R., Seifert, R. A., Soriano, P., and Bowen-Pope, D. F. (1998). Chimaeric analysis reveals role of Pdgf receptors in all muscle lineages. Nat. Genet. 18, 385-388. doi: 10.1038/ng0498-385

Daly, C. J., and McGrath, J. C. (2011). Previously unsuspected widespread cellular and tissue distribution of beta-adrenoceptors and its relevance to drug action. Trends Pharmacol. Sci. 32, 219-226. doi: 10.1016/j.tips.2011.02.008

Danbolt, N. C., Storm-Mathisen, J., and Kanner, B. I. (1992). An [Na++ $\mathrm{K}+$ ] coupled L-glutamate transporter purified from rat brain is located in glial cell processes. Neuroscience 51, 295-310. doi: 10.1016/0306-4522(92) 90316-T

Dar, A., Domev, H., Ben-Yosef, O., Tzukerman, M., Zeevi-Levin, N., Novak, A., et al. (2012). Multipotent vasculogenic pericytes from human pluripotent stem cells promote recovery of murine ischemic limb. Circulation 125, 87-99. doi: 10.1161/CIRCULATIONAHA.111.048264

Darland, D. C., Massingham, L. J., Smith, S. R., Piek, E., Saint-Geniez, M., and D'Amore, P. A. (2003). Pericyte production of cell-associated VEGF is differentiation-dependent and is associated with endothelial survival. Dev. Biol. 264, 275-288. doi: 10.1016/j.ydbio.2003.08.015

Davis, S., Aldrich, T. H., Jones, P. F., Acheson, A., Compton, D. L., Jain, V., et al. (1996). Isolation of angiopoietin-1, a ligand for the TIE2 receptor, by secretion-trap expression cloning. Cell 87, 1161-1169. doi: 10.1016/S00928674(00)81812-7

Delbono, O. (2011). "Excitation-contraction coupling in Aging SkeletalMuscle," in Advances in Experimental Medicine and Biology Series, ed G. S. Lynch (Heidelberg: Springer-Verlag), 113-135.

Delbono, O. (2003). Neural control of aging skeletal muscle. Aging Cell 2, 21-29. doi: 10.1046/j.1474-9728.2003.00011.x

Dellavalle, A., Maroli, G., Covarello, D., Azzoni, E., Innocenzi, A., Perani, L., et al. (2011). Pericytes resident in postnatal skeletal muscle differentiate into muscle fibres and generate satellite cells. Nat. Commun. 2, 499. doi: $10.1038 /$ ncomms 1508

Dellavalle, A., Sampaolesi, M., Tonlorenzi, R., Tagliafico, E., Sacchetti, B., Perani, L., et al. (2007). Pericytes of human skeletal muscle are myogenic precursors distinct from satellite cells. Nat. Cell Biol. 9, 255-267. doi: 10.1038/ncb1542

Diaz-Flores, L., Gutierrez, R., and Varela, H. (1992b). Behavior of postcapillary venule pericytes during postnatal angiogenesis. J. Morphol. 213, 33-45. doi: 10.1002/jmor.1052130105

Diaz-Flores, L., Gutierrez, R., and Varela, H. (1994b). Angiogenesis: an update. Histol. Histopathol. 9, 807-843.

Diaz-Flores, L., Gutierrez, R., Lopez-Alonso, A., Gonzalez, R., and Varela, H. (1992a). Pericytes as a supplementary source of osteoblasts in periosteal osteogenesis. Clin. Orthop. Relat. Res. 275, 280-286.

Diaz-Flores, L., Gutierrez, R., Valladares, F., Varela, H., and Perez, M. (1994a). Intense vascular sprouting from rat femoral vein induced by prostaglandins E1 and E2. Anat. Rec. 238, 68-76. doi: 10.1002/ar.1092380109

Diaz-Flores, L., Gutierrez, R., Varela, H., Rancel, N., and Valladares, F. (1991). Microvascular pericytes: a review of their morphological and functional characteristics. Histol. Histopathol. 6, 269-286.

Doherty, T. J., Vandervoort, A. A., Taylor, A. W., and Brown, W. F. (1993). Effects of motor unit losses on strength in older men and women. J. Appl. Physiol. 74, $868-874$.

Dooley, S., and Ten Dijke, P. (2012). TGF-beta in progression of liver disease. Cell Tissue Res. 347, 245-256. doi: 10.1007/s00441-011-1246-y

Dore-Duffy, P., Katychev, A., Wang, X., and Van Buren, E. (2006). CNS microvascular pericytes exhibit multipotential stem cell activity. J. Cereb. Blood Flow Metab. 26, 613-624. doi: 10.1038/sj.jcbfm.9600272

Drowley, L., Okada, M., Beckman, S., Vella, J., Keller, B., Tobita, K., et al. (2010). Cellular antioxidant levels influence muscle stem cell therapy. Mol. Ther. 18, 1865-1873. doi: 10.1038/mt.2010.160

Dulauroy, S., Di Carlo, S. E., Langa, F., Eberl, G., and Peduto, L. (2012). Lineage tracing and genetic ablation of $\operatorname{ADAM} 12(+)$ perivascular cells identify a major source of profibrotic cells during acute tissue injury. Nat. Med. 18, 1262-1270. doi: $10.1038 / \mathrm{nm} .2848$

Egginton, S. (2009). Invited review: activity-induced angiogenesis. Pflugers Arch. 457, 963-977. doi: 10.1007/s00424-008-0563-9

Egginton, S., Hudlicka, O., Brown, M. D., Graciotti, L., and Granata, A. L. (1996). In vivo pericyte-endothelial cell interaction during angiogenesis in adult cardiac and skeletal muscle. Microvasc. Res. 51, 213-228. doi: 10.1006/mvre. 1996.0022 
Ehm, O., Goritz, C., Covic, M., Schaffner, I., Schwarz, T. J., Karaca, E., et al. (2010). RBPJkappa-dependent signaling is essential for long-term maintenance of neural stem cells in the adult hippocampus. J. Neurosci. 30, 13794-13807. doi: 10.1523/JNEUROSCI.1567-10.2010

Einsiedel, L. J., and Luff, A. R. (1992). Effect of partial denervation on motor units in the ageing rat medial gastrocnemius. J. Neurol. Sci. 112, 178-184. doi: 10.1016/0022-510X(92)90148-E

Elfont, R. M., Sundaresan, P. R., and Sladek, C. D. (1989). Adrenergic receptors on cerebral microvessels: pericyte contribution. Am. J. Physiol. 256, R224-R230.

Encinas, J. M., Michurina, T. V., Peunova, N., Park, J. H., Tordo, J., Peterson, D. A., et al. (2011). Division-coupled astrocytic differentiation and age-related depletion of neural stem cells in the adult hippocampus. Cell Stem Cell 8, 566-579. doi: 10.1016/j.stem.2011.03.010

Enge, M., Bjarnegard, M., Gerhardt, H., Gustafsson, E., Kalen, M., Asker, N., et al. (2002). Endothelium-specific platelet-derived growth factor-B ablation mimics diabetic retinopathy. EMBO J. 21, 4307-4316. doi: 10.1093/emboj/cdf418

Erovic, B. M., Harris, L., Jamali, M., Goldstein, D. P., Irish, J. C., Asa, S. L., et al. (2012). Biomarkers of parathyroid carcinoma. Endocr. Pathol. 23, 221-231. doi: 10.1007/s12022-012-9222-y

Etchevers, H. C., Vincent, C., Le Douarin, N. M., and Couly, G. F. (2001). The cephalic neural crest provides pericytes and smooth muscle cells to all blood vessels of the face and forebrain. Development 128, 1059-1068.

Farrington-Rock, C., Crofts, N. J., Doherty, M. J., Ashton, B. A., GriffinJones, C., and Canfield, A. E. (2004). Chondrogenic and adipogenic potential of microvascular pericytes. Circulation 110, 2226-2232. doi: 10.1161/01.CIR.0000144457.55518.E5

Feinberg, M. W. (2013). OutFOXing myeloid cells in atherosclerosis with FoxOs. Circ. Res. 112, 978-982. doi: 10.1161/CIRCRESAHA.113.301159

Ferenbach, D. A., Sheldrake, T. A., Dhaliwal, K., Kipari, T. M., Marson, L. P., Kluth, D. C., et al. (2012). Macrophage/monocyte depletion by clodronate, but not diphtheria toxin, improves renal ischemia/reperfusion injury in mice. Kidney Int. 82, 928-933. doi: 10.1038/ki.2012.207

Ferrara, N., and Kerbel, R. S. (2005). Angiogenesis as a therapeutic target. Nature 438, 967-974. doi: 10.1038/nature04483

Ferrari-Dileo, G., Davis, E. B., and Anderson, D. R. (1992). Effects of cholinergic and adrenergic agonists on adenylate cyclase activity of retinal microvascular pericytes in culture. Invest. Ophthalmol. Vis. Sci. 33, 42-47.

Folkman, J. (1971). Tumor angiogenesis: therapeutic implications. N. Engl. J. Med. 285, 1182-1186. doi: 10.1056/NEJM197111182852108

Folkman, J. (1995). Seminars in Medicine of the Beth Israel Hospital, Boston. Clinical applications of research on angiogenesis. N. Engl. J. Med. 333, 1757-1763. doi: 10.1056/NEJM199512283332608

Forsythe, J. A., Jiang, B. H., Iyer, N. V., Agani, F., Leung, S. W., Koos, R. D., et al. (1996). Activation of vascular endothelial growth factor gene transcription by hypoxia-inducible factor 1. Mol. Cell. Biol. 16, 4604-4613.

Friedman, H. C., Jelsma, T. N., Bray, G. M., and Aguayo, A. J. (1996). A distinct pattern of trophic factor expression in myelin-deficient nerves of Trembler mice: implications for trophic support by Schwann cells. J. Neurosci. 16, 5344-5350.

Frostick, S. P., Yin, Q., and Kemp, G. J. (1998). Schwann cells, neurotrophic factors, and peripheral nerve regeneration. Microsurgery 18, 397-405.

Fruttiger, M., Karlsson, L., Hall, A. C., Abramsson, A., Calver, A. R., Bostrom, H., et al. (1999). Defective oligodendrocyte development and severe hypomyelination in PDGF-A knockout mice. Development 126, 457-467.

Fukushima, K., Badlani, N., Usas, A., Riano, F., Fu, F., and Huard, J. (2001). The use of an antifibrosis agent to improve muscle recovery after laceration. Am. J. Sports Med. 29, 394-402.

Funakoshi, H., Frisen, J., Barbany, G., Timmusk, T., Zachrisson, O., Verge, V. M., et al. (1993). Differential expression of mRNAs for neurotrophins and their receptors after axotomy of the sciatic nerve. J. Cell Biol. 123, 455-465. doi: 10.1083/jcb.123.2.455

Fuoco, C., Sangalli, E., Vono, R., Testa, S., Sacchetti, B., Latronico, M. V., et al. (2014). 3D hydrogel environment rejuvenates aged pericytes for skeletal muscle tissue engineering. Front. Physiol. 5:203. doi: 10.3389/fphys.2014.00203

Gannon, F. H., Kaplan, F. S., Olmsted, E., Finkel, G. C., Zasloff, M. A., and Shore, E. (1997). Bone morphogenetic protein $2 / 4$ in early fibromatous lesions of fibrodysplasia ossificans progressiva. Hum. Pathol. 28, 339-343. doi: 10.1016/S0046-8177(97)90133-7

Gargioli, C., Coletta, M., De Grandis, F., Cannata, S. M., and Cossu, G. (2008). PlGF-MMP-9-expressing cells restore microcirculation and efficacy of cell therapy in aged dystrophic muscle. Nat. Med. 14, 973-978. doi: 10.1038/ nm. 1852

Gerhardt, H., and Betsholtz, C. (2003). Endothelial-pericyte interactions in angiogenesis. Cell Tissue Res. 314, 15-23. doi: 10.1007/s00441-003-0745-x

Gharaibeh, B., Chun-Lansinger, Y., Hagen, T., Ingham, S. J., Wright, V., Fu, F, et al. (2012). Biological approaches to improve skeletal muscle healing after injury and disease. Birth Defects Res. C Embryo Today 96, 82-94. doi: 10.1002/bdrc. 21005

Giacca, M., and Zacchigna, S. (2012). VEGF gene therapy: therapeutic angiogenesis in the clinic and beyond. Gene Ther. 19, 622-629. doi: 10.1038/gt. 2012.17

Giordano, A., and Galderisi, U. (2010). Cell Cycle Regulation and Differentiation in Cardiovascular and Neural Systems. New York, NY: Springer Science \& Business Media. doi: 10.1007/978-1-60327-153-0

Glass, D. J. (2010). Signaling pathways perturbing muscle mass. Curr. Opin. Clin. Nutr. Metab. Care 13, 225-229. doi: 10.1097/MCO.0b013e32833862df

Gnessi, L., Emidi, A., Scarpa, S., Palleschi, S., Ragano-Caracciolo, M., Silvestroni, L., et al. (1993). Platelet-derived growth factor effects on purified testicular peritubular myoid cells: binding, cytosolic $\mathrm{Ca} 2+$ increase, mitogenic activity, and extracellular matrix production enhancement. Endocrinology 133, 1880-1890. doi: 10.1210/endo.133.4.8404630

Goldspink, G., Fernandes, K., Williams, P. E., and Wells, D. J. (1994). Age-related changes in collagen gene expression in the muscles of $\mathrm{mdx}$ dystrophic and normal mice. Neuromuscul. Disord. 4, 183-191. doi: 10.1016/0960-8966(94) 90019-1

Goodpaster, B. H., and Wolf, D. (2004). Skeletal muscle lipid accumulation in obesity, insulin resistance, and type 2 diabetes. Pediatr. Diabetes 5, 219-226. doi: 10.1111/j.1399-543X.2004.00071.x

Goodpaster, B. H., Stenger, V. A., Boada, F., McKolanis, T., Davis, D., Ross, R., et al. (2004). Skeletal muscle lipid concentration quantified by magnetic resonance imaging. Am. J. Clin. Nutr. 79, 748-754.

Goretzki, L., Lombardo, C. R., and Stallcup, W. B. (2000). Binding of the NG2 proteoglycan to kringle domains modulates the functional properties of angiostatin and plasmin(ogen). J. Biol. Chem. 275, 28625-28633. doi: 10.1074/jbc.M002290200

Goritz, C., Dias, D. O., Tomilin, N., Barbacid, M., Shupliakov, O., and Frisen, J. (2011). A pericyte origin of spinal cord scar tissue. Science 333, 238-242. doi: 10.1126/science. 1203165

Graham, K. M., Singh, R., Millman, G., Malnassy, G., Gatti, F., Bruemmer, K., et al. (2010). Excessive collagen accumulation in dystrophic ( $\mathrm{mdx}$ ) respiratory musculature is independent of enhanced activation of the NF-kappaB pathway. J. Neurol. Sci. 294, 43-50. doi: 10.1016/j.jns.2010.04.007

Grako, K. A., Ochiya, T., Barritt, D., Nishiyama, A., and Stallcup, W. B. (1999). PDGF (alpha)-receptor is unresponsive to PDGF-AA in aortic smooth muscle cells from the NG2 knockout mouse. J. Cell Sci. 112(Pt 6), 905-915.

Grako, K. A., and Stallcup, W. B. (1995). Participation of the NG2 proteoglycan in rat aortic smooth muscle cell responses to platelet-derived growth factor. Exp. Cell Res. 221, 231-240. doi: 10.1006/excr.1995.1371

Greco, A. V., Mingrone, G., Giancaterini, A., Manco, M., Morroni, M., Cinti, S., et al. (2002). Insulin resistance in morbid obesity: reversal with intramyocellular fat depletion. Diabetes 51, 144-151. doi: 10.2337/diabetes.51.1.144

Grenier, G., Leblanc, E., Faucheux, N., Lauzier, D., Kloen, P., and Hamdy, R. C. (2013). BMP-9 expression in human traumatic heterotopic ossification: a case report. Skelet. Muscle 3:29. doi: 10.1186/2044-5040-3-29

Gronthos, S., and Simmons, P. J. (1996). The biology and application of human bone marrow stromal cell precursors. J. Hematother. 5, 15-23. doi: 10.1089/scd.1.1996.5.15

Guida, T., Anaganti, S., Provitera, L., Gedrich, R., Sullivan, E., Wilhelm, S. M., et al. (2007). Sorafenib inhibits imatinib-resistant KIT and platelet-derived growth factor receptor beta gatekeeper mutants. Clin. Cancer Res. 13, 3363-3369. doi: 10.1158/1078-0432.CCR-06-2667

Gussoni, E., Soneoka, Y., Strickland, C. D., Buzney, E. A., Khan, M. K., Flint, A. F., et al. (1999). Dystrophin expression in the $\mathrm{mdx}$ mouse restored by stem cell transplantation. Nature 401, 390-394. doi: 10.1038/43919

Gustafsson, T., Puntschart, A., Kaijser, L., Jansson, E., and Sundberg, C. J. (1999). Exercise-induced expression of angiogenesis-related transcription and growth factors in human skeletal muscle. Am. J. Physiol. 276, H679-H685.

Hamano, K., Li, T. S., Kobayashi, T., Tanaka, N., Kobayashi, S., Matsuzaki, M., et al. (2001). The induction of angiogenesis by the implantation of autologous bone 
marrow cells: a novel and simple therapeutic method. Surgery 130, 44-54. doi: 10.1067/msy.2001.114762

Hashizume, K., Kanda, K., and Burke, R. E. (1988). Medial gastrocnemius motor nucleus in the rat: age-related changes in the number and size of motoneurons. J. Comp. Neurol. 269, 425-430. doi: 10.1002/cne.902690309

Haus, J. M., Carrithers, J. A., Trappe, S. W., and Trappe, T. A. (2007). Collagen, cross-linking, and advanced glycation end products in aging human skeletal muscle. J. Appl. Physiol. 103, 2068-2076. doi: 10.1152/japplphysiol.00670.2007

Hawinkels, L. J., and Ten Dijke, P. (2011). Exploring anti-TGF-beta therapies in cancer and fibrosis. Growth Factors 29, 140-152. doi: 10.3109/08977194.2011.595411

He, W., Nieponice, A., Soletti, L., Hong, Y., Gharaibeh, B., Crisan, M., et al. (2010). Pericyte-based human tissue engineered vascular grafts. Biomaterials 31, 8235-8244. doi: 10.1016/j.biomaterials.2010.07.034

Heglind, M., Cederberg, A., Aquino, J., Lucas, G., Ernfors, P., and Enerback, S. (2005). Lack of the central nervous system- and neural crest-expressed forkhead gene Foxs1 affects motor function and body weight. Mol. Cell. Biol. 25, 5616-5625. doi: 10.1128/MCB.25.13.5616-5625.2005

Hegyi, L., Gannon, F. H., Glaser, D. L., Shore, E. M., Kaplan, F. S., and Shanahan, C. M. (2003). Stromal cells of fibrodysplasia ossificans progressiva lesions express smooth muscle lineage markers and the osteogenic transcription factor Runx2/Cbfa-1: clues to a vascular origin of heterotopic ossification? J. Pathol. 201, 141-148. doi: 10.1002/path.1413

Heil, M., and Schaper, W. (2004). Influence of mechanical, cellular, and molecular factors on collateral artery growth (arteriogenesis). Circ. Res. 95, 449-458. doi: 10.1161/01.RES.0000141145.78900.44

Heldin, C. H., Landstrom, M., and Moustakas, A. (2009). Mechanism of TGF-beta signaling to growth arrest, apoptosis, and epithelial-mesenchymal transition. Curr. Opin. Cell Biol. 21, 166-176. doi: 10.1016/j.ceb.2009.01.021

Hellstrom, M., Gerhardt, H., Kalen, M., Li, X., Eriksson, U., Wolburg, H., et al. (2001). Lack of pericytes leads to endothelial hyperplasia and abnormal vascular morphogenesis. J. Cell Biol. 153, 543-553. doi: 10.1083/jcb.153.3.543

Hellstrom, M., Kalen, M., Lindahl, P., Abramsson, A., and Betsholtz, C. (1999). Role of PDGF-B and PDGFR-beta in recruitment of vascular smooth muscle cells and pericytes during embryonic blood vessel formation in the mouse. Development 126, 3047-3055.

Herzog, E. L., and Bucala, R. (2010). Fibrocytes in health and disease. Exp. Hematol. 38, 548-556. doi: 10.1016/j.exphem.2010.03.004

Hinz, B., Phan, S. H., Thannickal, V. J., Prunotto, M., Desmouliere, A., Varga, J., et al. (2012). Recent developments in myofibroblast biology: paradigms for connective tissue remodeling. Am. J. Pathol. 180, 1340-1355. doi: 10.1016/j.ajpath.2012.02.004

Hirschi, K. K., Burt, J. M., Hirschi, K. D., and Dai, C. (2003). Gap junction communication mediates transforming growth factor-beta activation and endothelial-induced mural cell differentiation. Circ. Res. 93, 429-437. doi: 10.1161/01.RES.0000091259.84556.D5

Huard, J., Li, Y., and Fu, F. H. (2002). Muscle injuries and repair: current trends in research. J. Bone Joint Surg. Am. 84-A, 822-832.

Hyldahl, R. D., Xin, L., Hubal, M. J., Moeckel-Cole, S., Chipkin, S., and Clarkson, P. M. (2011). Activation of nuclear factor-kappaB following muscle eccentric contractions in humans is localized primarily to skeletal muscle-residing pericytes. FASEB J. 25, 2956-2966. doi: 10.1096/fj.10-177105

Irion, G. L., Vasthare, U. S., and Tuma, R. F. (1987). Age-related change in skeletal muscle blood flow in the rat. J. Gerontol. 42, 660-665. doi: 10.1093/geronj/42.6.660

Isner, J. M. (1996). Therapeutic angiogenesis: a new frontier for vascular therapy. Vasc. Med. 1, 79-87.

Isner, J. M., and Asahara, T. (1999). Angiogenesis and vasculogenesis as therapeutic strategies for postnatal neovascularization. J. Clin. Invest. 103, 1231-1236. doi: 10.1172/JCI6889

Iwase, T., Nagaya, N., Fujii, T., Itoh, T., Murakami, S., Matsumoto, T., et al. (2005). Comparison of angiogenic potency between mesenchymal stem cells and mononuclear cells in a rat model of hindlimb ischemia. Cardiovasc. Res. 66, 543-551. doi: 10.1016/j.cardiores.2005.02.006

Izumi, Y., Shimamoto, K., Benz, A. M., Hammerman, S. B., Olney, J. W., and Zorumski, C. F. (2002). Glutamate transporters and retinal excitotoxicity. Glia 39, 58-68. doi: 10.1002/glia.10082

Janssen, I., Heymsfield, S. B., and Ross, R. (2002). Low relative skeletal muscle mass (sarcopenia) in older persons is associated with functional impairment and physical disability. J. Am. Geriatr. Soc. 50, 889-896. doi: 10.1046/j.15325415.2002.50216.x

Jarvinen, T. A., Jarvinen, T. L., Kaariainen, M., Kalimo, H., and Jarvinen, M. (2005). Muscle injuries: biology and treatment. Am. J. Sports Med. 33, 745-764. doi: 10.1177/0363546505274714

Jarvinen, T. A., Jozsa, L., Kannus, P., Jarvinen, T. L., and Jarvinen, M. (2002). Organization and distribution of intramuscular connective tissue in normal and immobilized skeletal muscles. An immunohistochemical, polarization and scanning electron microscopic study. J. Muscle Res. Cell Motil. 23, 245-254. doi: 10.1023/A:1020904518336

Joe, A. W., Yi, L., Natarajan, A., Le Grand, F., So, L., Wang, J., et al. (2010). Muscle injury activates resident fibro/adipogenic progenitors that facilitate myogenesis. Nat. Cell Biol. 12, 153-163. doi: 10.1038/ncb2015

Johnson, C., Sung, H. J., Lessner, S. M., Fini, M. E., and Galis, Z. S. (2004). Matrix metalloproteinase- 9 is required for adequate angiogenic revascularization of ischemic tissues: potential role in capillary branching. Circ. Res. 94, 262-268. doi: 10.1161/01.RES.0000111527.42357.62

Johnson, H., Mossberg, K., Arvidsson, U., Piehl, F., Hokfelt, T., and Ulfhake, B. (1995). Increase in alpha-CGRP and GAP-43 in aged motoneurons: a study of peptides, growth factors, and ChAT mRNA in the lumbar spinal cord of senescent rats with symptoms of hindlimb incapacities. J. Comp. Neurol. 359, 69-89. doi: 10.1002/cne.903590106

Jorgensen, L. H., Jensen, C. H., Wewer, U. M., and Schroder, H. D. (2007). Transgenic overexpression of ADAM12 suppresses muscle regeneration and aggravates dystrophy in aged mdx mice. Am. J. Pathol. 171, 1599-1607. doi: 10.2353/ajpath.2007.070435

Juhas, M., and Bursac, N. (2013). Engineering skeletal muscle repair. Curr. Opin. Biotechnol. 24, 880-886. doi: 10.1016/j.copbio.2013.04.013

Jung, K. H., Chu, K., Lee, S. T., Bahn, J. J., Jeon, D., Kim, J. H., et al. (2011). Multipotent PDGFRbeta-expressing cells in the circulation of stroke patients. Neurobiol. Dis. 41, 489-497. doi: 10.1016/j.nbd.2010.10.020

Kaariainen, M., Jarvinen, T., Jarvinen, M., Rantanen, J., and Kalimo, H. (2000). Relation between myofibers and connective tissue during muscle injury repair. Scand. J. Med. Sci. Sports 10, 332-337. doi: 10.1034/j.16000838.2000.010006332.x

Kale, S., Hanai, J., Chan, B., Karihaloo, A., Grotendorst, G., Cantley, L., et al. (2005). Microarray analysis of in vitro pericyte differentiation reveals an angiogenic program of gene expression. FASEB J. 19, 270-271. doi: 10.1096/fj.041604fje

Kalenderer, O., Bozoglan, M., and Agus, H. (2012). Heterotopic ossification in quadratus femoris muscle in a haemophilic patient. Haemophilia 18, e13-e14. doi: 10.1111/j.1365-2516.2011.02637.x

Kalka, C., Masuda, H., Takahashi, T., Kalka-Moll, W. M., Silver, M., Kearney, M., et al. (2000). Transplantation of ex vivo expanded endothelial progenitor cells for therapeutic neovascularization. Proc. Natl. Acad. Sci. U.S.A. 97, 3422-3427. doi: 10.1073/pnas.97.7.3422

Kan, L., Liu, Y., McGuire, T. L., Berger, D. M., Awatramani, R. B., Dymecki, S. M., et al. (2009). Dysregulation of local stem/progenitor cells as a common cellular mechanism for heterotopic ossification. Stem Cells 27, 150-156. doi: 10.1634/stemcells.2008-0576

Kan, L., Peng, C. Y., McGuire, T. L., and Kessler, J. A. (2013). Glast-expressing progenitor cells contribute to heterotopic ossification. Bone 53, 194-203. doi: 10.1016/j.bone.2012.12.008

Kanda, K., and Hashizume, K. (1989). Changes in properties of the medial gastrocnemius motor units in aging rats. J. Neurophysiol. 61, 737-746.

Kanda, K., and Hashizume, K. (1992). Factors causing difference in force output among motor units in the rat medial gastrocnemius muscle. J. Physiol. (Lond). 448, 677-695.

Kang, H., Tian, L., Mikesh, M., Lichtman, J. W., and Thompson, W. J. (2014). Terminal Schwann cells participate in neuromuscular synapse remodeling during reinnervation following nerve injury. J. Neurosci. 34, 6323-6333. doi: 10.1523/JNEUROSCI.4673-13.2014

Kang, H., Tian, L., Son, Y. J., Zuo, Y., Procaccino, D., Love, F., et al. (2007). Regulation of the intermediate filament protein nestin at rodent neuromuscular junctions by innervation and activity. J. Neurosci. 27, 5948-5957. doi: 10.1523/JNEUROSCI.0621-07.2007

Kang, J. S., Liu, C., and Derynck, R. (2009). New regulatory mechanisms of TGF-beta receptor function. Trends Cell Biol. 19, 385-394. doi: 10.1016/j.tcb.2009.05.008 
Kaplan, F. S., Chakkalakal, S. A., and Shore, E. M. (2012). Fibrodysplasia ossificans progressiva: mechanisms and models of skeletal metamorphosis. Dis. Model. Mech. 5, 756-762. doi: 10.1242/dmm.010280

Karlsson, L., Bondjers, C., and Betsholtz, C. (1999). Roles for PDGF-A and sonic hedgehog in development of mesenchymal components of the hair follicle. Development 126, 2611-2621.

Karlsson, L., Lindahl, P., Heath, J. K., and Betsholtz, C. (2000). Abnormal gastrointestinal development in PDGF-A and PDGFR-(alpha) deficient mice implicates a novel mesenchymal structure with putative instructive properties in villus morphogenesis. Development 127, 3457-3466.

Kasemkijwattana, C., Menetrey, J., Somogyl, G., Moreland, M. S., Fu, F. H., Buranapanitkit, B., et al. (1998). Development of approaches to improve the healing following muscle contusion. Cell Transplant. 7, 585-598. doi: 10.1016/S0963-6897(98)00037-2

Kawabuchi, M., Tan, H., and Wang, S. (2011). Age affects reciprocal cellular interactions in neuromuscular synapses following peripheral nerve injury. Ageing Res. Rev. 10, 43-53. doi: 10.1016/j.arr.2010.10.003

Kelley, C., D'Amore, P., Hechtman, H. B., and Shepro, D. (1988). Vasoactive hormones and cAMP affect pericyte contraction and stress fibres in vitro. J. Muscle Res. Cell Motil. 9, 184-194. doi: 10.1007/BF01773740

Kikkawa, N., Ohno, T., Nagata, Y., Shiozuka, M., Kogure, T., and Matsuda, R. (2009). Ectopic calcification is caused by elevated levels of serum inorganic phosphate in mdx mice. Cell Struct. Funct. 34, 77-88. doi: 10.1247/csf.08039

Kilarski, W. W., Samolov, B., Petersson, L., Kvanta, A., and Gerwins, P. (2009). Biomechanical regulation of blood vessel growth during tissue vascularization. Nat. Med. 15, 657-664. doi: 10.1038/nm.1985

Kim, S. W., and Choi, J. H. (2009). Myositis ossificans in psoas muscle after lumbar spine fracture. Spine 34, E367-E370. doi: 10.1097/BRS.0b013e31819b30bf

Kondo, T., Case, J., Srour, E. F., and Hashino, E. (2006). Skeletal musclederived progenitor cells exhibit neural competence. Neuroreport 17, 1-4. doi: 10.1097/01.wnr.0000192732.00535.ff

Korn, J., Christ, B., and Kurz, H. (2002). Neuroectodermal origin of brain pericytes and vascular smooth muscle cells. J. Comp. Neurol. 442, 78-88. doi: $10.1002 /$ cne. 1423

Kragstrup, T. W., Kjaer, M., and Mackey, A. L. (2011). Structural, biochemical, cellular, and functional changes in skeletal muscle extracellular matrix with aging. Scand. J. Med. Sci. Sports 21, 749-757. doi: 10.1111/j.1600-0838.2011.01377.x

Kunz, J., Krause, D., Kremer, M., and Dermietzel, R. (1994). The 140-kDa protein of blood-brain barrier-associated pericytes is identical to aminopeptidase N. J. Neurochem. 62, 2375-2386. doi: 10.1046/j.1471-4159.1994.62062375.x

Kuznetsov, S. A., Mankani, M. H., Gronthos, S., Satomura, K., Bianco, P., and Robey, P. G. (2001). Circulating skeletal stem cells. J. Cell Biol. 153, 1133-1140. doi: $10.1083 /$ jcb.153.5.1133

Kwan, P. (2013). Sarcopenia: the gliogenic perspective. Mech. Ageing Dev. 134, 349-355. doi: 10.1016/j.mad.2013.06.001

Labbe, R., Lindsay, T., and Walker, P. M. (1987). The extent and distribution of skeletal muscle necrosis after graded periods of complete ischemia. J. Vasc. Surg. 6, 152-157. doi: 10.1067/mva.1987.avs0060152

Lakner, A. M., Moore, C. C., Gulledge, A. A., and Schrum, L. W. (2010). Daily genetic profiling indicates JAK/STAT signaling promotes early hepatic stellate cell transdifferentiation. World J. Gastroenterol. 16, 5047-5056. doi: 10.3748/wjg.v16.i40.5047

Lamalice, L., Houle, F., and Huot, J. (2006). Phosphorylation of Tyr1214 within VEGFR-2 triggers the recruitment of Nck and activation of Fyn leading to SAPK2/p38 activation and endothelial cell migration in response to VEGF. J. Biol. Chem. 281, 34009-34020. doi: 10.1074/jbc.M603928200

Larsson, L. (1995). Motor units: remodeling in aged animals. J. Gerontol. A Biol. Sci. Med. Sci. 50(Spec No), 91-95.

Lavasani, M., Lu, A., Peng, H., Cummins, J., and Huard, J. (2006). Nerve growth factor improves the muscle regeneration capacity of muscle stem cells in dystrophic muscle. Hum. Gene Ther. 17, 180-192. doi: 10.1089/hum.2006. 17.180

Lavasani, M., Thompson, S. D., Pollett, J. B., Usas, A., Lu, A., Stolz, D. B., et al. (2014). Human muscle-derived stem/progenitor cells promote functional murine peripheral nerve regeneration. J. Clin. Invest. 124, 1745-1756. doi: 10.1172/JCI44071

Lebleu, V. S., Taduri, G., O’Connell, J., Teng, Y., Cooke, V. G., Woda, C., et al. (2013). Origin and function of myofibroblasts in kidney fibrosis. Nat. Med. 19, 1047-1053. doi: $10.1038 / \mathrm{nm} .3218$
Lee, D., Boscolo, E., Durham, J. T., Mulliken, J. B., Herman, I. M., and Bischoff, J. (2014). Propranolol targets contractility of infantile hemangioma-derived pericytes. Br. J. Dermatol. doi: 10.1111/bjd.13048. [Epub ahead of print].

Lee, J. Y., Qu-Petersen, Z., Cao, B., Kimura, S., Jankowski, R., Cummins, J., et al. (2000). Clonal isolation of muscle-derived cells capable of enhancing muscle regeneration and bone healing. J. Cell Biol. 150, 1085-1100. doi: $10.1083 /$ jcb.150.5.1085

Lee, Y. H., and Granneman, J. G. (2012). Seeking the source of adipocytes in adult white adipose tissues. Adipocyte 1, 230-236. doi: 10.4161/adip.20804

Lehre, K. P., Levy, L. M., Ottersen, O. P., Storm-Mathisen, J., and Danbolt, N. C. (1995). Differential expression of two glial glutamate transporters in the rat brain: quantitative and immunocytochemical observations. J. Neurosci. 15, 1835-1853.

Lepper, C., Partridge, T. A., and Fan, C. M. (2011). An absolute requirement for Pax7-positive satellite cells in acute injury-induced skeletal muscle regeneration. Development 138, 3639-3646. doi: 10.1242/dev.067595

Levy, L. M., Lehre, K. P., Rolstad, B., and Danbolt, N. C. (1993). A monoclonal antibody raised against an $[\mathrm{Na}(+)+\mathrm{K}+]$ coupled L-glutamate transporter purified from rat brain confirms glial cell localization. FEBS Lett. 317, 79-84. doi: 10.1016/0014-5793(93)81495-L

Levy, M. M., Joyner, C. J., Virdi, A. S., Reed, A., Triffitt, J. T., Simpson, A. H., et al. (2001). Osteoprogenitor cells of mature human skeletal muscle tissue: an in vitro study. Bone 29, 317-322. doi: 10.1016/S8756-3282(01)00585-3

Lewis, C., and Murdoch, C. (2005). Macrophage responses to hypoxia: implications for tumor progression and anti-cancer therapies. Am. J. Pathol. 167, 627-635. doi: 10.1016/S0002-9440(10)62038-X

Li, G., Zheng, B., Meszaros, L. B., Vella, J. B., Usas, A., Matsumoto, T., et al. (2011). Identification and characterization of chondrogenic progenitor cells in the fascia of postnatal skeletal muscle. J. Mol. Cell Biol. 3, 369-377. doi: $10.1093 / \mathrm{jmcb} / \mathrm{mjr} 014$

Li, S., Huang, N. F., and Hsu, S. (2005). Mechanotransduction in endothelial cell migration. J. Cell. Biochem. 96, 1110-1126. doi: 10.1002/jcb.20614

Li, Y., Foster, W., Deasy, B. M., Chan, Y., Prisk, V., Tang, Y., et al. (2004). Transforming growth factor-betal induces the differentiation of myogenic cells into fibrotic cells in injured skeletal muscle: a key event in muscle fibrogenesis. Am. J. Pathol. 164, 1007-1019. doi: 10.1016/S0002-9440(10)63188-4

Li, Y., and Huard, J. (2002). Differentiation of muscle-derived cells into myofibroblasts in injured skeletal muscle. Am. J. Pathol. 161, 895-907. doi: 10.1016/S00029440(10)64250-2

Li, Y., and Thompson, W. J. (2011). Nerve terminal growth remodels neuromuscular synapses in mice following regeneration of the postsynaptic muscle fiber. J. Neurosci. 31, 13191-13203. doi: 10.1523/JNEUROSCI.2953-11.2011

Li, Y., Xu, S., Jiang, B., Cohen, R. A., and Zang, M. (2013). Activation of sterol regulatory element binding protein and NLRP3 inflammasome in atherosclerotic lesion development in diabetic pigs. PLoS ONE 8:e67532. doi: 10.1371/journal.pone.0067532

Li, Z. B., Kollias, H. D., and Wagner, K. R. (2008). Myostatin directly regulates skeletal muscle fibrosis. J. Biol. Chem. 283, 19371-19378. doi: 10.1074/jbc.M8025 85200

Lieber, R. L., and Ward, S. R. (2013). Cellular mechanisms of tissue fibrosis. 4. Structural and functional consequences of skeletal muscle fibrosis. Am. J. Physiol. Cell Physiol. 305, C241-C252. doi: 10.1152/ajpcell.00173.2013

Lin, C. C., Lee, I. T., Chi, P. L., Hsieh, H. L., Cheng, S. E., Hsiao, L. D., et al. (2014). C-Src/Jak2/PDGFR/PKCdelta-dependent MMP-9 induction is required for thrombin-stimulated rat brain astrocytes migration. Mol. Neurobiol. 49, 658-672. doi: 10.1007/s12035-013-8547-y

Lindahl, P., Johansson, B. R., Leveen, P., and Betsholtz, C. (1997). Pericyte loss and microaneurysm formation in PDGF-B-deficient mice. Science 277, 242-245. doi: 10.1126/science.277.5323.242

Liu, F., Woitge, H. W., Braut, A., Kronenberg, M. S., Lichtler, A. C., Mina, M., et al. (2004). Expression and activity of osteoblast-targeted Cre recombinase transgenes in murine skeletal tissues. Int. J. Dev. Biol. 48, 645-653. doi: 10.1387/ijdb. $041816 \mathrm{fl}$

Lounev, V. Y., Ramachandran, R., Wosczyna, M. N., Yamamoto, M., Maidment, A. D., Shore, E. M., et al. (2009). Identification of progenitor cells that contribute to heterotopic skeletogenesis. J. Bone Joint Surg. Am. 91, 652-663. doi: 10.2106/JBJS.H.01177

Maes, C., Kobayashi, T., Selig, M. K., Torrekens, S., Roth, S. I., Mackem, S., et al. (2010). Osteoblast precursors, but not mature osteoblasts, move into developing 
and fractured bones along with invading blood vessels. Dev. Cell 19, 329-344. doi: 10.1016/j.devcel.2010.07.010

Magill, C. K., Tong, A., Kawamura, D., Hayashi, A., Hunter, D. A., Parsadanian, A., et al. (2007). Reinnervation of the tibialis anterior following sciatic nerve crush injury: a confocal microscopic study in transgenic mice. Exp. Neurol. 207, 64-74. doi: 10.1016/j.expneurol.2007.05.028

Mann, C. J., Perdiguero, E., Kharraz, Y., Aguilar, S., Pessina, P., Serrano, A. L., et al. (2011). Aberrant repair and fibrosis development in skeletal muscle. Skelet. Muscle 1, 21. doi: 10.1186/2044-5040-1-21

Massague, J. (2012). TGFbeta signalling in context. Nat. Rev. Mol. Cell Biol. 13, 616-630. doi: 10.1038/nrm3434

Massague, J., Seoane, J., and Wotton, D. (2005). Smad transcription factors. Genes Dev. 19, 2783-2810. doi: 10.1101/gad.1350705

McCarthy, J. J., Mula, J., Miyazaki, M., Erfani, R., Garrison, K., Farooqui, A. B., et al. (2011). Effective fiber hypertrophy in satellite cell-depleted skeletal muscle. Development 138, 3657-3666. doi: 10.1242/dev.068858

McCulloch, P. C., and Bush-Joseph, C. A. (2006). Massive heterotopic ossification complicating iliopsoas tendon lengthening: a case report. Am. J. Sports Med. 34, 2022-2025. doi: 10.1177/0363546506290668

McPherron, A. C., Lawler, A. M., and Lee, S. J. (1997). Regulation of skeletal muscle mass in mice by a new TGF-beta superfamily member. Nature $387,83-90$. doi: 10.1038/387083a0

Medici, D., Shore, E. M., Lounev, V. Y., Kaplan, F. S., Kalluri, R., and Olsen, B. R. (2010). Conversion of vascular endothelial cells into multipotent stem-like cells. Nat. Med. 16, 1400-1406. doi: 10.1038/nm.2252

Mendez-Ferrer, S., Battista, M., and Frenette, P. S. (2010a). Cooperation of beta(2)and beta(3)-adrenergic receptors in hematopoietic progenitor cell mobilization. Ann. N.Y. Acad. Sci. 1192, 139-144. doi: 10.1111/j.1749-6632.2010.05390.x

Mendez-Ferrer, S., Michurina, T. V., Ferraro, F., Mazloom, A. R., Macarthur, B. D., Lira, S. A., et al. (2010b). Mesenchymal and haematopoietic stem cells form a unique bone marrow niche. Nature 466, 829-834. doi: 10.1038/nature09262

Mitchell, K. J., Pannerec, A., Cadot, B., Parlakian, A., Besson, V., Gomes, E. R., et al. (2010). Identification and characterization of a non-satellite cell muscle resident progenitor during postnatal development. Nat. Cell Biol. 12, 257-266. doi: $10.1038 /$ ncb2025

Mohan, S., and Radha, E. (1980). Age-related changes in rat muscle collagen. Gerontology 26, 61-67. doi: 10.1159/000212396

Moldovan, N. I., Goldschmidt-Clermont, P. J., Parker-Thornburg, J., Shapiro, S. D., and Kolattukudy, P. E. (2000). Contribution of monocytes/macrophages to compensatory neovascularization: the drilling of metalloelastasepositive tunnels in ischemic myocardium. Circ. Res. 87, 378-384. doi: 10.1161/01.RES.87.5.378

Morales, M. G., Gutierrez, J., Cabello-Verrugio, C., Cabrera, D., Lipson, K. E., Goldschmeding, R., et al. (2013). Reducing CTGF/CCN2 slows down mdx muscle dystrophy and improves cell therapy. Hum. Mol. Genet. 22, 4938-4951. doi: 10.1093/hmg/ddt352

Morikawa, S., Baluk, P., Kaidoh, T., Haskell, A., Jain, R. K., and McDonald, D. M. (2002). Abnormalities in pericytes on blood vessels and endothelial sprouts in tumors. Am. J. Pathol. 160, 985-1000. doi: 10.1016/S0002-9440(10) 64920-6

Mu, X., Usas, A., Tang, Y., Lu, A., Wang, B., Weiss, K., et al. (2013). RhoA mediates defective stem cell function and heterotopic ossification in dystrophic muscle of mice. FASEB J. 27, 3619-3631. doi: 10.1096/fj.13-233460

Murata, T., Ishibashi, T., Inomata, H., and Sueishi, K. (1994). Media conditioned by coculture of pericytes and endothelial cells under a hypoxic state stimulate in vitro angiogenesis. Ophthalmic Res. 26, 23-31. doi: 10.1159/000267370

Murdoch, C., and Lewis, C. E. (2005). Macrophage migration and gene expression in response to tumor hypoxia. Int. J. Cancer 117, 701-708. doi: $10.1002 /$ ijc. 21422

Murdoch, C., Muthana, M., and Lewis, C. E. (2005). Hypoxia regulates macrophage functions in inflammation. J. Immunol. 175, 6257-6263. doi: 10.4049/jimmunol.175.10.6257

Murohara, T., Asahara, T., Silver, M., Bauters, C., Masuda, H., Kalka, C., et al. (1998). Nitric oxide synthase modulates angiogenesis in response to tissue ischemia. J. Clin. Invest. 101, 2567-2578. doi: 10.1172/JCI1560

Murphy, M. M., Lawson, J. A., Mathew, S. J., Hutcheson, D. A., and Kardon, G. (2011). Satellite cells, connective tissue fibroblasts and their interactions are crucial for muscle regeneration. Development 138, 3625-3637. doi: $10.1242 /$ dev.064162
Nakagomi, T., Molnar, Z., Nakano-Doi, A., Taguchi, A., Saino, O., Kubo, S., et al. (2011). Ischemia-induced neural stem/progenitor cells in the pia mater following cortical infarction. Stem Cells Dev. 20, 2037-2051. doi: $10.1089 /$ scd.2011.0279

Negroni, E., Riederer, I., Chaouch, S., Belicchi, M., Razini, P., Di Santo, J., et al. (2009). In vivo myogenic potential of human CD133+ muscle-derived stem cells: a quantitative study. Mol. Ther. 17, 1771-1778. doi: 10.1038/mt.2009.167

Nehls, V., Denzer, K., and Drenckhahn, D. (1992). Pericyte involvement in capillary sprouting during angiogenesis in situ. Cell Tissue Res. 270, 469-474. doi: 10.1007/BF00645048

Nguyen, Q. T., Sanes, J. R., and Lichtman, J. W. (2002). Pre-existing pathways promote precise projection patterns. Nat. Neurosci. 5, 861-867. doi: 10.1038/nn905

Niimi, H. (2003). Cerebral angiogenesis induced by growth factors: intravital microscopic studies using models. Clin. Hemorheol. Microcirc. 29, 149-156.

Nikawa, T., Ishidoh, K., Hirasaka, K., Ishihara, I., Ikemoto, M., Kano, M., et al. (2004). Skeletal muscle gene expression in space-flown rats. FASEB J. 18, 522-524. doi: 10.1096/fj.03-0419fje

Nishimura, R., Hata, K., Matsubara, T., Wakabayashi, M., and Yoneda, T. (2012). Regulation of bone and cartilage development by network between BMP signalling and transcription factors. J. Biochem. 151, 247-254. doi: $10.1093 / \mathrm{jb} / \mathrm{mvs004}$

Ohlendieck, K. (2011). Proteomic profiling of fast-to-slow muscle transitions during aging. Front. Physiol. 2:105. doi: 10.3389/fphys.2011.00105

Oishi, T., Uezumi, A., Kanaji, A., Yamamoto, N., Yamaguchi, A., Yamada, H., et al. (2013). Osteogenic differentiation capacity of human skeletal muscle-derived progenitor cells. PLoS ONE 8:e56641. doi: 10.1371/journal.pone.0056641

Olson, L. E., and Soriano, P. (2009). Increased PDGFRalpha activation disrupts connective tissue development and drives systemic fibrosis. Dev. Cell 16, 303-313. doi: 10.1016/j.devcel.2008.12.003

Ostman, A. (2004). PDGF receptors-mediators of autocrine tumor growth and regulators of tumor vasculature and stroma. Cytokine Growth Factor Rev. 15, 275-286. doi: 10.1016/j.cytogfr.2004.03.002

Ozerdem, U., and Stallcup, W. B. (2003). Early contribution of pericytes to angiogenic sprouting and tube formation. Angiogenesis 6, 241-249. doi: 10.1023/B:AGEN.0000021401.58039.a9

Ozerdem, U., Grako, K. A., Dahlin-Huppe, K., Monosov, E., and Stallcup, W. B. (2001). NG2 proteoglycan is expressed exclusively by mural cells during vascular morphogenesis. Dev. Dyn. 222, 218-227. doi: 10.1002/dvdy.1200

Padua, D., and Massague, J. (2009). Roles of TGFbeta in metastasis. Cell Res. 19, 89-102. doi: 10.1038/cr.2008.316

Pannerec, A., Formicola, L., Besson, V., Marazzi, G., and Sassoon, D. A. (2013). Defining skeletal muscle resident progenitors and their cell fate potentials. Development 140, 2879-2891. doi: 10.1242/dev.089326

Paquet-Fifield, S., Schluter, H., Li, A., Aitken, T., Gangatirkar, P., Blashki, D., et al. (2009). A role for pericytes as microenvironmental regulators of human skin tissue regeneration. J. Clin. Invest. 119, 2795-2806. doi: 10.1172/JCI38535

Pardali, E., and Ten Dijke, P. (2012). TGFbeta signaling and cardiovascular diseases. Int. J. Biol. Sci. 8, 195-213. doi: 10.7150/ijbs.3805

Park, Y. S., Kim, N. H., and Jo, I. (2003). Hypoxia and vascular endothelial growth factor acutely up-regulate angiopoietin- 1 and Tie2 mRNA in bovine retinal pericytes. Microvasc. Res. 65, 125-131. doi: 10.1016/S0026-2862(02) 00035-3

Peault, B., Rudnicki, M., Torrente, Y., Cossu, G., Tremblay, J. P., Partridge, T., et al. (2007). Stem and progenitor cells in skeletal muscle development, maintenance, and therapy. Mol. Ther. 15, 867-877. doi: 10.1038/mt.sj.6300145

Polak, J. F., Jolesz, F. A., and Adams, D. F. (1988). Magnetic resonance imaging of skeletal muscle. Prolongation of T1 and T2 subsequent to denervation. Invest. Radiol. 23, 365-369. doi: 10.1097/00004424-198805000-00007

Poole, D. C., Barstow, T. J., McDonough, P., and Jones, A. M. (2008). Control of oxygen uptake during exercise. Med. Sci. Sports Exerc. 40, 462-474. doi: 10.1249/MSS.0b013e31815ef29b

Popa-Wagner, A., Dinca, I., Yalikun, S., Walker, L., Kroemer, H., and Kessler, C. (2006). Accelerated delimitation of the infarct zone by capillary-derived nestin-positive cells in aged rats. Curr. Neurovasc. Res. 3, 3-13. doi: $10.2174 / 156720206775541732$

Quignard, J. F., Harley, E. A., Duhault, J., Vanhoutte, P. M., and Feletou, M. (2003). $\mathrm{K}+$ channels in cultured bovine retinal pericytes: effects of beta-adrenergic stimulation. J. Cardiovasc. Pharmacol. 42, 379-388. doi: 10.1097/00005344200309000-00009 
Qu-Petersen, Z., Deasy, B., Jankowski, R., Ikezawa, M., Cummins, J., Pruchnic, R., et al. (2002). Identification of a novel population of muscle stem cells in mice: potential for muscle regeneration. J. Cell Biol. 157, 851-864. doi: $10.1083 /$ jcb. 200108150

Reilly, T. M., Seldes, R., Luchetti, W., and Brighton, C. T. (1998). Similarities in the phenotypic expression of pericytes and bone cells. Clin. Orthop. Relat. Res. 346, 95-103.

Reinmuth, N., Liu, W., Jung, Y. D., Ahmad, S. A., Shaheen, R. M., Fan, F., et al. (2001). Induction of VEGF in perivascular cells defines a potential paracrine mechanism for endothelial cell survival. FASEB J. 15, 1239-1241. doi: 10.1096/fj.00-0693fje

Relaix, F., and Zammit, P. S. (2012). Satellite cells are essential for skeletal muscle regeneration: the cell on the edge returns centre stage. Development 139, 2845-2856. doi: 10.1242/dev.069088

Reynolds, L. P., Grazul-Bilska, A. T., and Redmer, D. A. (2000). Angiogenesis in the corpus luteum. Endocrine 12, 1-9. doi: 10.1385/ENDO:12:1:1

Rich, M. M., and Lichtman, J. W. (1989). In vivo visualization of pre- and postsynaptic changes during synapse elimination in reinnervated mouse muscle. J. Neurosci. 9, 1781-1805.

Rivard, A., Fabre, J. E., Silver, M., Chen, D., Murohara, T., Kearney, M., et al. (1999). Age-dependent impairment of angiogenesis. Circulation 99, 111-120. doi: 10.1161/01.CIR.99.1.111

Rodeheffer, M. S. (2010). Tipping the scale: muscle versus fat. Nat. Cell Biol. 12, 102-104. doi: 10.1038/ncb0210-102

Romero-Ramos, M., Vourc'h, P., Young, H. E., Lucas, P. A., Wu, Y., Chivatakarn, O., et al. (2002). Neuronal differentiation of stem cells isolated from adult muscle. J. Neurosci. Res. 69, 894-907. doi: 10.1002/jnr.10374

Rousseau, S., Houle, F., and Huot, J. (2000). Integrating the VEGF signals leading to actin-based motility in vascular endothelial cells. Trends Cardiovasc. Med. 10, 321-327. doi: 10.1016/S1050-1738(01)00072-X

Rowan, S. L., Rygiel, K., Purves-Smith, F. M., Solbak, N. M., Turnbull, D. M., and Hepple, R. T. (2012). Denervation causes fiber atrophy and myosin heavy chain co-expression in senescent skeletal muscle. PLoS ONE 7:e29082. doi: 10.1371/journal.pone.0029082

Rucker, H. K., Wynder, H. J., and Thomas, W. E. (2000). Cellular mechanisms of CNS pericytes. Brain Res. Bull. 51, 363-369. doi: 10.1016/S03619230(99)00260-9

Ryall, J. G., Schertzer, J. D., and Lynch, G. S. (2008). Cellular and molecular mechanisms underlying age-related skeletal muscle wasting and weakness. Biogerontology 9, 213-228. doi: 10.1007/s10522-008-9131-0

Sacchetti, B., Funari, A., Michienzi, S., Di Cesare, S., Piersanti, S., Saggio, I., et al. (2007). Self-renewing osteoprogenitors in bone marrow sinusoids can organize a hematopoietic microenvironment. Cell 131, 324-336. doi: 10.1016/j.cell.2007.08.025

Sambasivan, R., Yao, R., Kissenpfennig, A., Van Wittenberghe, L., Paldi, A., Gayraud-Morel, B., et al. (2011). Pax7-expressing satellite cells are indispensable for adult skeletal muscle regeneration. Development 138, 3647-3656. doi: 10.1242/dev.067587

Sampaolesi, M., Blot, S., D'antona, G., Granger, N., Tonlorenzi, R., Innocenzi, A., et al. (2006). Mesoangioblast stem cells ameliorate muscle function in dystrophic dogs. Nature 444, 574-579. doi: 10.1038/nature05282

Sampaolesi, M., Torrente, Y., Innocenzi, A., Tonlorenzi, R., D'antona, G., Pellegrino, M. A., et al. (2003). Cell therapy of alpha-sarcoglycan null dystrophic mice through intra-arterial delivery of mesoangioblasts. Science 301, 487-492. doi: 10.1126/science.1082254

Sasaki, K., Murohara, T., Ikeda, H., Sugaya, T., Shimada, T., Shintani, S., et al. (2002). Evidence for the importance of angiotensin II type 1 receptor in ischemia-induced angiogenesis. J. Clin. Invest. 109, 603-611. doi: 10.1172/JCI13055

Sato, K., Li, Y., Foster, W., Fukushima, K., Badlani, N., Adachi, N., et al. (2003). Improvement of muscle healing through enhancement of muscle regeneration and prevention of fibrosis. Muscle Nerve 28, 365-372. doi: 10.1002/mus. 10436

Sato, Y., and Rifkin, D. B. (1989). Inhibition of endothelial cell movement by pericytes and smooth muscle cells: activation of a latent transforming growth factor-beta 1-like molecule by plasmin during co-culture. J. Cell Biol. 109, 309-315. doi: 10.1083/jcb.109.1.309
Schaper, W., and Scholz, D. (2003). Factors regulating arteriogenesis. Arterioscler. Thromb. Vasc. Biol. 23, 1143-1151. doi: 10.1161/01.ATV.0000069625. 11230.96

Schoefl, G. I. (1963). Studies on inflammation. Iii. Growing Capillaries: their structure and permeability. Virchows Arch. Pathol. Anat. Physiol. Klin. Med. 337, 97-141.

Schultz, S. S., and Lucas, P. A. (2006). Human stem cells isolated from adult skeletal muscle differentiate into neural phenotypes. J. Neurosci. Methods 152, 144-155. doi: 10.1016/j.jneumeth.2005.08.022

Sendtner, M., Stockli, K. A., and Thoenen, H. (1992). Synthesis and localization of ciliary neurotrophic factor in the sciatic nerve of the adult rat after lesion and during regeneration. J. Cell Biol. 118, 139-148. doi: 10.1083/jcb.118.1.139

Shepro, D., and Morel, N. M. (1993). Pericyte physiology. FASEB J. 7, 1031-1038.

Shi, S., and Gronthos, S. (2003). Perivascular niche of postnatal mesenchymal stem cells in human bone marrow and dental pulp. J. Bone Miner. Res. 18, 696-704. doi: 10.1359/jbmr.2003.18.4.696

Shibata, R., Ouchi, N., Kihara, S., Sato, K., Funahashi, T., and Walsh, K. (2004). Adiponectin stimulates angiogenesis in response to tissue ischemia through stimulation of amp-activated protein kinase signaling. J. Biol. Chem. 279, 28670-28674. doi: 10.1074/jbc.M402558200

Shibata, T., Yamada, K., Watanabe, M., Ikenaka, K., Wada, K., Tanaka, K., et al. (1997). Glutamate transporter GLAST is expressed in the radial glia-astrocyte lineage of developing mouse spinal cord. J. Neurosci. 17, 9212-9219.

Shimada, T., Takeshita, Y., Murohara, T., Sasaki, K., Egami, K., Shintani, S., et al. (2004). Angiogenesis and vasculogenesis are impaired in the precocious-aging klotho mouse. Circulation 110, 1148-1155. doi: 10.1161/01.CIR.0000139854.74847.99

Shimizu, F., Sano, Y., Abe, M. A., Maeda, T., Ohtsuki, S., Terasaki, T., et al. (2011). Peripheral nerve pericytes modify the blood-nerve barrier function and tight junctional molecules through the secretion of various soluble factors. J. Cell. Physiol. 226, 255-266. doi: 10.1002/jcp.22337

Shintani, S., Murohara, T., Ikeda, H., Ueno, T., Sasaki, K., Duan, J., et al. (2001). Augmentation of postnatal neovascularization with autologous bone marrow transplantation. Circulation 103, 897-903. doi: 10.1161/01.CIR.103.6.897

Shireman, P. K. (2007). The chemokine system in arteriogenesis and hind limb ischemia. J. Vasc. Surg. 45(Suppl. A), A48-A56. doi: 10.1016/j.jvs.2007.02.030

Shireman, P. K., and Quinones, M. P. (2005). Differential necrosis despite similar perfusion in mouse strains after ischemia. J. Surg. Res. 129, 242-250. doi: 10.1016/j.jss.2005.06.013

Sholley, M. M., Gimbrone, M. A. Jr., and Cotran, R. S. (1977). Cellular migration and replication in endothelial regeneration: a study using irradiated endothelial cultures. Lab. Invest. 36, 18-25.

Shore, E. M., and Kaplan, F. S. (2010). Inherited human diseases of heterotopic bone formation. Nat. Rev. Rheumatol. 6, 518-527. doi: $10.1038 /$ nrrheum. 2010.122

Sica, A. (2010). Macrophages give Gas(6) to cancer. Blood 115, 2122-2123. doi: 10.1182/blood-2009-12-255869

Silvestre, J. S., Mallat, Z., Duriez, M., Tamarat, R., Bureau, M. F., Scherman, D., et al. (2000). Antiangiogenic effect of interleukin-10 in ischemia-induced angiogenesis in mice hindlimb. Circ. Res. 87, 448-452. doi: 10.1161/01.RES.87.6.448

Sims, D. E. (2000). Diversity within pericytes. Clin. Exp. Pharmacol. Physiol. 27, 842-846. doi: 10.1046/j.1440-1681.2000.03343.x

Sirvanci, M., Ganiyusufoglu, A. K., Karaman, K., Tezer, M., and Hamzaoglu, A. (2004). Myositis ossificans of psoas muscle: magnetic resonance imaging findings. Acta Radiol. 45, 523-525. doi: 10.1080/02841850410005697

Slezak, M., Goritz, C., Niemiec, A., Frisen, J., Chambon, P., Metzger, D., et al. (2007). Transgenic mice for conditional gene manipulation in astroglial cells. Glia 55, 1565-1576. doi: 10.1002/glia.20570

Solomon, E., Li, H., Duhachek Muggy, S., Syta, E., and Zolkiewska, A. (2010). The role of SnoN in transforming growth factor betal-induced expression of metalloprotease-disintegrin ADAM12. J. Biol. Chem. 285, 21969-21977. doi: 10.1074/jbc.M110.133314

Sonveaux, P., Martinive, P., Dewever, J., Batova, Z., Daneau, G., Pelat, M., et al. (2004). Caveolin-1 expression is critical for vascular endothelial growth factor-induced ischemic hindlimb collateralization and nitric oxidemediated angiogenesis. Circ. Res. 95, 154-161. doi: 10.1161/01.RES.0000136344. 27825.72 
Soriano, P. (1997). The PDGF alpha receptor is required for neural crest cell development and for normal patterning of the somites. Development 124, 2691-2700.

Sousa-Victor, P., Gutarra, S., Garcia-Prat, L., Rodriguez-Ubreva, J., Ortet, L., RuizBonilla, V., et al. (2014). Geriatric muscle stem cells switch reversible quiescence into senescence. Nature 506, 316-321. doi: 10.1038/nature13013

Steinbrech, D. S., Mehrara, B. J., Chau, D., Rowe, N. M., Chin, G., Lee, T., et al. (1999). Hypoxia upregulates VEGF production in keloid fibroblasts. Ann. Plast. Surg. 42, 514-519; discussion: 519-520. doi: 10.1097/00000637-19990500000009

Sun, G., Haginoya, K., Wu, Y., Chiba, Y., Nakanishi, T., Onuma, A., et al. (2008). Connective tissue growth factor is overexpressed in muscles of human muscular dystrophy. J. Neurol. Sci. 267, 48-56. doi: 10.1016/j.jns.2007.09.043

Swijnenburg, R. J., Tanaka, M., Vogel, H., Baker, J., Kofidis, T., Gunawan, F., et al. (2005). Embryonic stem cell immunogenicity increases upon differentiation after transplantation into ischemic myocardium. Circulation 112, I166-172. doi: 10.1161/CIRCULATIONAHA.104.525824

Tedesco, F. S., Gerli, M. F., Perani, L., Benedetti, S., Ungaro, F., Cassano, M., et al. (2012). Transplantation of genetically corrected human iPSC-derived progenitors in mice with limb-girdle muscular dystrophy. Sci. Transl. Med. 4:140ra189. doi: 10.1126/scitranslmed.3003541

Tedgui, A., and Mallat, Z. (2006). Cytokines in atherosclerosis: pathogenic and regulatory pathways. Physiol. Rev. 86, 515-581. doi: 10.1152/physrev. 00024.2005

Thiery, J. P., Acloque, H., Huang, R. Y., and Nieto, M. A. (2009). Epithelialmesenchymal transitions in development and disease. Cell 139, 871-890. doi: 10.1016/j.cell.2009.11.007

Thompson, L. V. (2009). Age-related muscle dysfunction. Exp. Gerontol. 44, 106-111. doi: 10.1016/j.exger.2008.05.003

Thorseth, K. (1968). A case of traumatic myositis ossificans in the iliopsoas muscle. Acta Orthop. Scand. 39, 73-75. doi: 10.3109/17453676808989440

Torrente, Y., Belicchi, M., Sampaolesi, M., Pisati, F., Meregalli, M., D’Antona, G., et al. (2004). Human circulating AC133(+) stem cells restore dystrophin expression and ameliorate function in dystrophic skeletal muscle. J. Clin. Invest. 114, 182-195. doi: 10.1172/JCI20325

Trensz, F., Haroun, S., Cloutier, A., Richter, M. V., and Grenier, G. (2010). A muscle resident cell population promotes fibrosis in hindlimb skeletal muscles of mdx mice through the Wnt canonical pathway. Am. J. Physiol. Cell Physiol. 299, C939-947. doi: 10.1152/ajpcell.00253.2010

Tsatsanis, C., and Spandidos, D. A. (2000). The role of oncogenic kinases in human cancer (Review). Int. J. Mol. Med. 5, 583-590. doi: 10.3892/ijmm.5.6.583

Tsuzuki, H., and Sasa, S. (1994). Ultrastructural observation of capillary sprouts in the dental organs of rat molars. Kaibogaku Zasshi 69, 684-696.

Uezumi, A., Fukada, S., Yamamoto, N., Ikemoto-Uezumi, M., Nakatani, M., Morita, M., et al. (2014). Identification and characterization of PDGFRalpha+ mesenchymal progenitors in human skeletal muscle. Cell Death Dis. 5, e1186. doi: $10.1038 /$ cddis.2014.161

Uezumi, A., Fukada, S., Yamamoto, N., Takeda, S., and Tsuchida, K. (2010). Mesenchymal progenitors distinct from satellite cells contribute to ectopic fat cell formation in skeletal muscle. Nat. Cell Biol. 12, 143-152. doi: $10.1038 /$ ncb2014

Uezumi, A., Ito, T., Morikawa, D., Shimizu, N., Yoneda, T., Segawa, M., et al. (2011). Fibrosis and adipogenesis originate from a common mesenchymal progenitor in skeletal muscle. J. Cell Sci. 124, 3654-3664. doi: 10.1242/jcs. 086629

Urish, K. L., Vella, J. B., Okada, M., Deasy, B. M., Tobita, K., Keller, B. B., et al. (2009). Antioxidant levels represent a major determinant in the regenerative capacity of muscle stem cells. Mol. Biol. Cell 20, 509-520. doi: 10.1091/mbc.E0803-0274

Valdez, G., Tapia, J. C., Kang, H., Clemenson, G. D. Jr., Gage, F. H., Lichtman, J. W., et al. (2010). Attenuation of age-related changes in mouse neuromuscular synapses by caloric restriction and exercise. Proc. Natl. Acad. Sci. U.S.A. 107, 14863-14868. doi: 10.1073/pnas.1002220107

Varu, V. N., Hogg, M. E., and Kibbe, M. R. (2010). Critical limb ischemia. J. Vasc. Surg. 51, 230-241. doi: 10.1016/j.jvs.2009.08.073

Verbeek, M. M., Otte-Holler, I., Wesseling, P., Ruiter, D. J., and De Waal, R. M. (1994). Induction of alpha-smooth muscle actin expression in cultured human brain pericytes by transforming growth factor-beta 1. Am. J. Pathol. 144, $372-382$.
Verdu, E., Ceballos, D., Vilches, J. J., and Navarro, X. (2000). Influence of aging on peripheral nerve function and regeneration. J. Peripher. Nerv. Syst. 5, 191-208. doi: 10.1046/j.1529-8027.2000.00026.x

Vial, C., Zuniga, L. M., Cabello-Verrugio, C., Canon, P., Fadic, R., and Brandan, E. (2008). Skeletal muscle cells express the profibrotic cytokine connective tissue growth factor (CTGF/CCN2), which induces their dedifferentiation. J. Cell. Physiol. 215, 410-421. doi: 10.1002/jcp.21324

Vignais, M. L., and Gilman, M. (1999). Distinct mechanisms of activation of Stat1 and Stat 3 by platelet-derived growth factor receptor in a cell-free system. Mol. Cell. Biol. 19, 3727-3735.

Vilquin, J. T., Catelain, C., and Vauchez, K. (2011). Cell therapy for muscular dystrophies: advances and challenges. Curr. Opin. Organ Transplant. 16, 640-649. doi: 10.1097/MOT.0b013e32834cfb70

Visser, M., Goodpaster, B. H., Kritchevsky, S. B., Newman, A. B., Nevitt, M., Rubin, S. M., et al. (2005). Muscle mass, muscle strength, and muscle fat infiltration as predictors of incident mobility limitations in well-functioning older persons. J. Gerontol. A Biol. Sci. Med. Sci. 60, 324-333. doi: 10.1093/gerona/ 60.3.324

Wahren, J., Saltin, B., Jorfeldt, L., and Pernow, B. (1974). Influence of age on the local circulatory adaptation to leg exercise. Scand. J. Clin. Lab. Invest. 33, 79-86. doi: 10.3109/00365517409114201

Walston, J. D. (2012). Sarcopenia in older adults. Curr. Opin. Rheumatol. 24, 623-627. doi: 10.1097/BOR.0b013e328358d59b

Weisser, S. B., Van Rooijen, N., and Sly, L. M. (2012). Depletion and reconstitution of macrophages in mice. J. Vis. Exp. 66:4105. doi: 10.3791/4105

Westvik, T. S., Fitzgerald, T. N., Muto, A., Maloney, S. P., Pimiento, J. M., Fancher, T. T., et al. (2009). Limb ischemia after iliac ligation in aged mice stimulates angiogenesis without arteriogenesis. J. Vasc. Surg. 49, 464-473. doi: 10.1016/j.jvs.2008.08.077

White, B. D., Nathe, R. J., Maris, D. O., Nguyen, N. K., Goodson, J. M., Moon, R. T., et al. (2010). Beta-catenin signaling increases in proliferating NG2+ progenitors and astrocytes during post-traumatic gliogenesis in the adult brain. Stem Cells 28, 297-307. doi: 10.1002/stem.268

Wosczyna, M. N., Biswas, A. A., Cogswell, C. A., and Goldhamer, D. J. (2012). Multipotent progenitors resident in the skeletal muscle interstitium exhibit robust BMP-dependent osteogenic activity and mediate heterotopic ossification. J. Bone Miner. Res. 27, 1004-1017. doi: 10.1002/jbmr.1562

Wren, T. A., Bluml, S., Tseng-Ong, L., and Gilsanz, V. (2008). Three-point technique of fat quantification of muscle tissue as a marker of disease progression in Duchenne muscular dystrophy: preliminary study. AJR Am. J. Roentgenol. 190, W8-W12. doi: 10.2214/AJR.07.2732

Wynn, T. A. (2007). Common and unique mechanisms regulate fibrosis in various fibroproliferative diseases. J. Clin. Invest. 117, 524-529. doi: 10.1172/ JCI31487

Wynn, T. A. (2008). Cellular and molecular mechanisms of fibrosis. J. Pathol. 214, 199-210. doi: 10.1002/path.2277

Xiong, W., Cheng, B. H., Jia, S. B., and Tang, L. S. (2010). Involvement of the PI3K/Akt signaling pathway in platelet-derived growth factor-induced migration of human lens epithelial cells. Curr. Eye Res. 35, 389-401. doi: $10.3109 / 02713680903584686$

Yamagishi, S., Yonekura, H., Yamamoto, Y., Fujimori, H., Sakurai, S., Tanaka, N., et al. (1999). Vascular endothelial growth factor acts as a pericyte mitogen under hypoxic conditions. Lab. Invest. 79, 501-509.

Yang, D. P., Kim, J., Syed, N., Tung, Y. J., Bhaskaran, A., Mindos, T., et al. (2012) p38 MAPK activation promotes denervated Schwann cell phenotype and functions as a negative regulator of Schwann cell differentiation and myelination. J. Neurosci. 32, 7158-7168. doi: 10.1523/JNEUROSCI.5812-11.2012

Yao, Y., Jumabay, M., Ly, A., Radparvar, M., Cubberly, M. R., and Bostrom, K. I. (2013). A role for the endothelium in vascular calcification. Circ. Res. 113, 495-504. doi: 10.1161/CIRCRESAHA.113.301792

Yin, H., Price, F., and Rudnicki, M. A. (2013). Satellite cells and the muscle stem cell niche. Physiol. Rev. 93, 23-67. doi: 10.1152/physrev.00043.2011

Young, J. Z. (1974). Functional recovery after lesions of the nervous system. VI. Conclusion. Functional recovery in vertebrates and invertebrates. Neurosci. Res. Program Bull. 12, 273-275.

Yu, J., Lei, L., Liang, Y., Hinh, L., Hickey, R. P., Huang, Y., et al. (2006). An engineered VEGF-activating zinc finger protein transcription factor improves blood flow and limb salvage in advanced-age mice. FASEB J. 20, 479-481. doi: 10.1096/fj.04-3670fje 
Yu, P. B., Deng, D. Y., Lai, C. S., Hong, C. C., Cuny, G. D., Bouxsein, M. L., et al. (2008). BMP type I receptor inhibition reduces heterotopic [corrected] ossification. Nat. Med. 14, 1363-1369. doi: 10.1038/nm.1888

Zammit, P. S., Partridge, T. A., and Yablonka-Reuveni, Z. (2006). The skeletal muscle satellite cell: the stem cell that came in from the cold. J. Histochem. Cytochem. 54, 1177-1191. doi: 10.1369/jhc.6R6995.2006

Zawadzka, M., Rivers, L. E., Fancy, S. P., Zhao, C., Tripathi, R., Jamen, F., et al. (2010). CNS-resident glial progenitor/stem cells produce Schwann cells as well as oligodendrocytes during repair of CNS demyelination. Cell Stem Cell 6, 578-590. doi: 10.1016/j.stem.2010.04.002

Zeisberg, E. M., Tarnavski, O., Zeisberg, M., Dorfman, A. L., McMullen, J. R., Gustafsson, E., et al. (2007). Endothelial-to-mesenchymal transition contributes to cardiac fibrosis. Nat. Med. 13, 952-961. doi: 10.1038/ nm1613

Zhang, C., Goto, N., Suzuki, M., and Ke, M. (1996). Age-related reductions in number and size of anterior horn cells at C6 level of the human spinal cord. Okajimas Folia Anat. Jpn. 73, 171-177. doi: 10.2535/ofaj1936.73.4_171

Zhang, X., Peault, B., Chen, W., Li, W., Corselli, M., James, A. W., et al. (2011). The Nell-1 growth factor stimulates bone formation by purified human perivascular cells. Tissue Eng. Part A 17, 2497-2509. doi: 10.1089/ten.tea. 2010.0705

Zheng, B., Cao, B., Crisan, M., Sun, B., Li, G., Logar, A., et al. (2007). Prospective identification of myogenic endothelial cells in human skeletal muscle. Nat. Biotechnol. 25, 1025-1034. doi: 10.1038/nbt1334
Zhu, J., Li, Y., Shen, W., Qiao, C., Ambrosio, F., Lavasani, M., et al. (2007). Relationships between transforming growth factor-betal, myostatin, and decorin: implications for skeletal muscle fibrosis. J. Biol. Chem. 282, 25852-25863. doi: 10.1074/jbc.M704146200

Zschauer, A. O., Davis, E. B., and Anderson, D. R. (1996). Glaucoma, capillaries and pericytes. 4. Beta-adrenergic activation of cultured retinal pericytes. Ophthalmologica 210, 276-279. doi: 10.1159/000310725

Conflict of Interest Statement: The authors declare that the research was conducted in the absence of any commercial or financial relationships that could be construed as a potential conflict of interest.

Received: 30 July 2014; paper pending published: 26 August 2014; accepted: 29 August 2014; published online: 18 September 2014.

Citation: Birbrair A, Zhang T, Wang Z-M, Messi ML, Mintz A and Delbono O (2014) Pericytes: multitasking cells in the regeneration of injured, diseased, and aged skeletal muscle. Front. Aging Neurosci. 6:245. doi: 10.3389/fnagi.2014.00245

This article was submitted to the journal Frontiers in Aging Neuroscience.

Copyright (c) 2014 Birbrair, Zhang, Wang, Messi, Mintz and Delbono. This is an open-access article distributed under the terms of the Creative Commons Attribution License (CC BY). The use, distribution or reproduction in other forums is permitted, provided the original author(s) or licensor are credited and that the original publication in this journal is cited, in accordance with accepted academic practice. No use, distribution or reproduction is permitted which does not comply with these terms. 